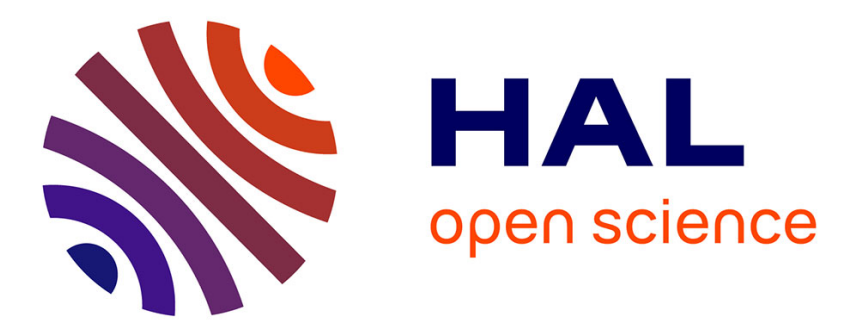

\title{
Edible caterpillars of Imbrasia truncata and Imbrasia epimethea contain lipids and proteins of high potential for nutrition
}

Aymar Fogang, Germain Kansci, Michèle Viau, Rodolphe Rougerie, Claude Genot

\section{To cite this version:}

Aymar Fogang, Germain Kansci, Michèle Viau, Rodolphe Rougerie, Claude Genot. Edible caterpillars of Imbrasia truncata and Imbrasia epimethea contain lipids and proteins of high potential for nutrition. Journal of Food Composition and Analysis, 2019, 79, pp.70-79. 10.1016/j.jfca.2019.03.002 . hal02613917

\section{HAL Id: hal-02613917 \\ https://hal.science/hal-02613917}

Submitted on 20 May 2020

HAL is a multi-disciplinary open access archive for the deposit and dissemination of scientific research documents, whether they are published or not. The documents may come from teaching and research institutions in France or abroad, or from public or private research centers.
L'archive ouverte pluridisciplinaire HAL, est destinée au dépôt et à la diffusion de documents scientifiques de niveau recherche, publiés ou non, émanant des établissements d'enseignement et de recherche français ou étrangers, des laboratoires publics ou privés. 


\title{
Edible caterpillars of Imbrasia truncata and Imbrasia epimethea contain lipids and proteins of high potential for nutrition
}

\author{
Aymar Rodrigue Fogang Mba ${ }^{\mathrm{a}, \mathrm{b}}$, , Germain Kansci ${ }^{\mathrm{a}}$, Michèle Viau ${ }^{\mathrm{b}}$, Rodolphe Rougerie ${ }^{\mathrm{c}}$, Claude Genot $^{\mathrm{b}}$ \\ ${ }^{a}$ University of Yaoundé I, Department of Biochemistry, Laboratory of Food Science and Metabolism, PO Box 812 Yaoundé, Cameroon \\ ${ }^{\mathrm{b}}$ UR 1268 BIA (Biopolymères Interactions Assemblages), INRA, 44300, Nantes, France \\ ${ }^{\mathrm{c}}$ Muséum national d'Histoire Naturelle de Paris, UMR 7205(MNHN, CNRS, UPMC, EPHE - Sorbonne Université), Institut de Systématique, Évolution, Biodiversité (ISYEB), 45Rue Buffon, CP50, \\ 75005, Paris, France
}

\section{ARTICLE INFO}

\section{Keywords:}

Amino acids

Caterpillar

Edible insects

Emperor moths

Fatty acids

Food analysis

Food composition

Imbrasia truncata

Imbrasia epimethea

$\mathrm{n}-6 / \mathrm{n}-3$ ratio

Nitrogen to protein conversion factor

Saturniidae

Vitamin E

\begin{abstract}
A B S T R A C T
Imbrasia truncata and $I$. epimethea caterpillars were evaluated as dietary protein and lipid sources. They contained approximately $7.0 \mathrm{~g} / 100 \mathrm{~g}$ fresh weight (FW) of lipids and $20.0 \mathrm{~g} / 100 \mathrm{~g} \mathrm{FW}$ of proteins calculed with determined nitrogen to protein conversion factors: $6.01 \pm 0.21$ and $6.27 \pm 0.15$ for $I$. truncata and $I$. epimethea, respectively. Unsaturated fatty acids represented about $2.63 \pm 0.21 \mathrm{~g} / 100 \mathrm{~g} \mathrm{FW}$ for $I$. truncata and $3.24 \pm 0.21 \mathrm{~g} /$ $100 \mathrm{~g}$ FW for $I$. epimethea, with $\alpha$-linolenic acid as major fatty acid (around $1.88 \pm 0.15 \mathrm{~g} / 100 \mathrm{~g}$ FW for $I$. truncata $2.17 \pm 0.13 \mathrm{~g} / 100 \mathrm{~g}$ FW for I. epimethea) and very low n-6/n-3 ratios: 0.15 (I. truncata) and 0.27 (I. epimethea). Polar lipids (phospholipids and glycolipids + sulfolipids), representing between 4 and 6\% of lipids, contained little amounts of arachidonic acid (C20:4n-6). The major tocopherol isomer was $\alpha$-tocopherol in $I$. truncata $(0.52 \pm 0.08 \mathrm{~g} / 100 \mathrm{~g} \mathrm{FW})$ and $\gamma$-tocopherol in I. epimethea $(1.00 \pm 0.08 \mathrm{~g} / 100 \mathrm{~g} \mathrm{FW})$. The proteins of both insect included all indispensable amino acids at amounts ( $\mathrm{mg} / \mathrm{g}$ protein) higher than the indispensable amino acid requirement patterns recommended by WHO/FAO/UNU (2007). In conclusion, Imbrasia caterpillars exhibit a great nutritional potential due to the presence of good quality proteins and healthy fat
\end{abstract}

\section{Introduction}

With a booming world population which is anticipated to reach approximately 10 billion people in 2050, the global food demand will increase by as much as $70 \%$ compared with our current food requirements (Zielińska et al., 2015). Food security stands on three pillars: food availability, food access and food use (Dube et al., 2013). Today, about 795 million people are undernourished worldwide with approximately 220 million in sub Saharan African countries(FAO - FIDA - WFP, 2015). Novel food sources should be investigated as alternative sources of proteins and energy, but also of other nutrients and micronutrients. Indeed food security requires a minimum daily energy intake but suboptimal diet is recognized as the leading risk factor for non-communicable diseases. An adequate diet should supply adequate amounts of nutrients and micronutrients. Proteins should carry adequate amounts of all essential amino acids (WHO/FAO/UNU, 2007). Adequate vitamins, minerals, essential fatty acids and dietary fibre are also required. Worldwide, intakes of polyunsaturated fats are far below optimal (Micha et al., 2015). Extremely low or low levels for plant omega-3 ( $\alpha$-linolenic acid) and omega-6 (linoleic acid) and seafood omega-3 (long-chain polyunsaturated fatty acids such as EPA and DHA) were identified in several countries in Sub-Saharan, West and Central Africa (Micha et al., 2015). Meta-analysis of randomized control feeding trials highlighted that polyunsaturated fatty acids (PUFA) have more favourable effects regarding improved glycaemia, insulin resistance, and insulin secretion capacity in comparison to carbohydrates, saturated fatty acids (SFA), or monounsaturated fatty acids (MUFA) (Imamura et al., 2016). Among PUFA, adequate equilibrium is also required between dietary omega- 6 and omega- 3 fatty acids to limit various diseases such as cardiovascular disease (Calder, 2015; Simopoulos, 2016). The Food and Agriculture Organization recommends edible insects as an alternative source of food and feed(Van Huis et al., 2013). Entomophagy, i.e., eating insects, is popular among people of many regions of the world including Africa, Asia, Australia, Central Mexico,

\footnotetext{
* Corresponding author at: University of Yaoundé I, Department of Biochemistry, Laboratory of Food Science and Metabolism, PO Box 812 Yaoundé, Cameroon.

Email address: aymarfogang@yahoo.fr (A.R. Fogang Mba)
} 
and South America (Defoliart, 1999). It is practiced by more than 2 billion people in the world (Van Huis et al., 2013). Insects are rich in proteins, lipids and several others micronutrients(Bukkens, 1997; Ramos-elorduy et al., 1997; Rumpold and Schlüter, 2013). The crude protein content of insects ranges from 40 to $75 \mathrm{~g} / 100 \mathrm{~g}$ dry weight (DW), largely depending on species and stage in the life cycle. Most of these values could however be overestimated due to the use of inadequate nitrogen-to-protein conversion factor and of proteins tightly embedded in the chitin matrix, and not digested by humans (Jonas-levi and Martinez, 2017). The fat content ranges from 0.66 to $77 \mathrm{~g} / 100 \mathrm{~g}$ DW, also depending on species, life stage and environment(Rumpold and Schlüter, 2013). Some edible insects contain dietary lipidswith essential PUFA) such as linoleic acid, $\alpha$-linolenic acid; long-chain PUFA such as eicosapentaenoic acid (EPA) and docosahexaenoic acid (DHA)having being detected in several species (Raksakantong et al., 2010; Rumpold and Schlüter, 2013; Sihamala et al, 2010; Yang et al., 2006).

Caterpillars of Emperor Moths (vernacular name of African Saturniidae (Oberprieler, 1997)) are among the most widely eaten insects in several African countries (Democratic Republic of the Congo, Republic of the Congo, Cameroon, Ivory Coast, etc) where they are highly appreciated by populations (Latham, 2008; Mabossy-Mobouna et al., 2013; Okangola et al., 2016). These insects are generally collected in the wild and sold in local markets. They contribute to the income of rural populations. They are also exported to Europe, particularly France and Belgium. In 2000, these two countries imported respectively from Democratic Republic of the Congo, 5 and 3 tons of dried Imbrasia sp. caterpillars, with an estimated value of 65,000 US $\$$ and 41,500 US $\$$.These insects are sold approximately $15.5 € / \mathrm{kg}$ in Belgium (Tabuna, 2000). In the European Union, insects have been recently covered by the new Novel Food Regulation, and may continue to be marketed throughout the EU (new Regulation (EU) 2015/2283).

Information about the nutritional composition of several Imbrasia species such as I. ertli, I. belina (mopane) and I. oyenensis are available in literature (Akpossan et al., 2014; Anvo et al., 2016; Foua et al., 2016; Glew et al., 1999; Kwiri et al., 2014; Santos Oliveira et al., 1976). These studies evidenced that proteins are major components of these insects, with profile of essential amino acids comparable to soybean and fish meal. Lipids represent the second main components. I. truncata and I. epimethea carterpillars are two species of Emperor moths. I. truncata is a Central African species wheareas I. epimethea is a Central and Western African species. The two species have some similar host plants. I. truncata feeds on Petersianthus macrocarpus, Ricinodendron heudelotii and Uapaca guinensis; I. epimethea feeds on Petersianthus macrocarpus, Ricinodendron heudelotii, Holarrhena floribunda, Pycnanthu sangolensis, Funtumia africana and acacia auriculiformis (Balinga et al., 2004; Latham, 2008; Lisingo et al., 2010) (Balinga et al., 2004; Latham, 2008; Lisingo et al., 2010). I. truncata and I. epimethea were found to have very close methods of preparations and nutritional compositions (Kokondi et al., 1987; Lautenschläger et al., 2017; Mabossy-Mobouna et al., 2017; Okangola et al., 2016). To our knowledge, no data on their tocopherol (vitamin E) composition nor on the fatty acid composition of lipid fractions (neutral lipids, phospholipids and glycolipids) have been already published.

The aim of the present study was to determine main nutritional features (proximate compositions, fatty acid and amino acid compositions, tocopherols) of two species of edible caterpillars in genus Imbrasia, (Emperor moths)and to provide new data about the characteristics of their lipid fraction (main lipid classes and their fatty acid compositions).

\section{Materials and methods}

\subsection{Sampling, identification and preparation of insects}

Three batches, each of approximately $500 \mathrm{~g}$ (71-84 animals) of two distinct species of edible caterpillars of Emperor moths were purchased alive at local markets of Yaoundé (Mvog Mbi, Mvog Atangana Mballa) and surroundings (Mfou). The living insects were washed with tap water, killed by freezing and stored at $-20^{\circ} \mathrm{C}$ for transportationto the Nantes laboratory where they were stored at $-80^{\circ} \mathrm{C}$ for about 1 month until further analysis. After morphological identification, including measurement of morphological parameters, their identity was confirmed by genetic identification using a DNA barcoding approach as described elsewhere(Hebert et al., 2003). Tissue samples (a small piece of thoracic leg) were processed through DNA extraction, PCR and sequencing of the standard barcode fragment of the COI mitochondrial gene following standard protocols at the Canadian Centre for DNA barcoding at the University of Guelph, Canada as described in Vaglia et al.(2008). Vouchers for the two specimens sampled (Fig. 1) are preserved at the Muséum National d'Histoire Naturelle in Paris, with codes EL5922 and EL 5923 for I. epimethea and I. truncata respectively. Specimen data, photographs and sequence data are available in the Barcode of Life Datasystems (BOLD; www.boldsystems.org) within the publicly accessible dataset DS-IMBR01 (https://doi.org/10. 5883 ds-imbr01). Sequences are also available from GenBank with accession codes MH571150 for I. epimethea and MH571150 for I. truncata. Identifications using the two generated DNA barcodes were carried out using BOLD identification engine (http://www.boldsystems.org/index. php/IDS_OpenIdEngine), which compares query sequences to existing sequences within the database.

Prior to analysis, approximately $100 \mathrm{~g}$ of frozen caterpillars of all batches $(n=3)$ of each Imbrasiasp were thawn. With a scalpel, each insect underwent a longitudinal operation of the abdomen to empty the gut containing toxic substances from the plants they ate. The head and viscera (digestive tract) were separated from the body by hands, as performed traditionally by households. Before analysis portions of each batch of eviscerated caterpillars $(2 \times 3$ batches $)$ were mixed together to form a single batch. For lipid extraction and lipid analysis, around $100 \mathrm{~g}$ of eviscerated insects (around 15 caterpillars) were taken from the three different batches and mixed together. Lipid extraction was performed on these mixed samples of eviscerated insects (1 sample for $I$. truncata and 1 sample for $I$ epimethea). For protein analysis, amino acids and ash analysis, more than 20 thawed and eviscerated insects were frozen again to be freeze-dried at $-80^{\circ} \mathrm{C}$ for $72 \mathrm{~h}$. The freeze-dried insects were milled using a laboratory mill $(20,000 \mathrm{rpm}$; M 20, IKA, Staufen, Germany) to prepare an homogenized insect flour sample, representative of the insects sold and consumed at Yaoundé. Protein, amino acid and ash analysis were performed on insect flour. The preparation and storage of insect flour followed the method described by Fogang Mba et al. (2017).

\subsection{Chemicals and solvents}

D-Glucosamic acid solution (Ref $0259>98 \%$ ), DL-norleucine (Ref $\mathrm{N} 1398>99.9 \%$ ), $\mathrm{HCl} 37 \%$, barium hydroxide, ninhydrin reagent solution (Ref29670511) and $\mathrm{BF}_{3} / \mathrm{CH}_{3} \mathrm{OH}(14 \%)$ wereof analytical grade and supplied by Sigma-Aldrich (Saint Quentin Fallavier, France).Eluting solvents for amino acid analysis (methanol/trifluoroacetic acid/formic acid solvents A to F, pH 2.94, 3.32, 4.48, 7.97and 10.5) and hydrochloric acid, lanthanum chloride, caesium chloride for mineral analysis were furnished by VWR (Strasbourg, France); chloroform (ethanol stabilized, HPLC grade), dichloromethane (amylenestabilized, HPLC grade), tert-butyl-methyl-ether (HPLC grade), n-hexane 


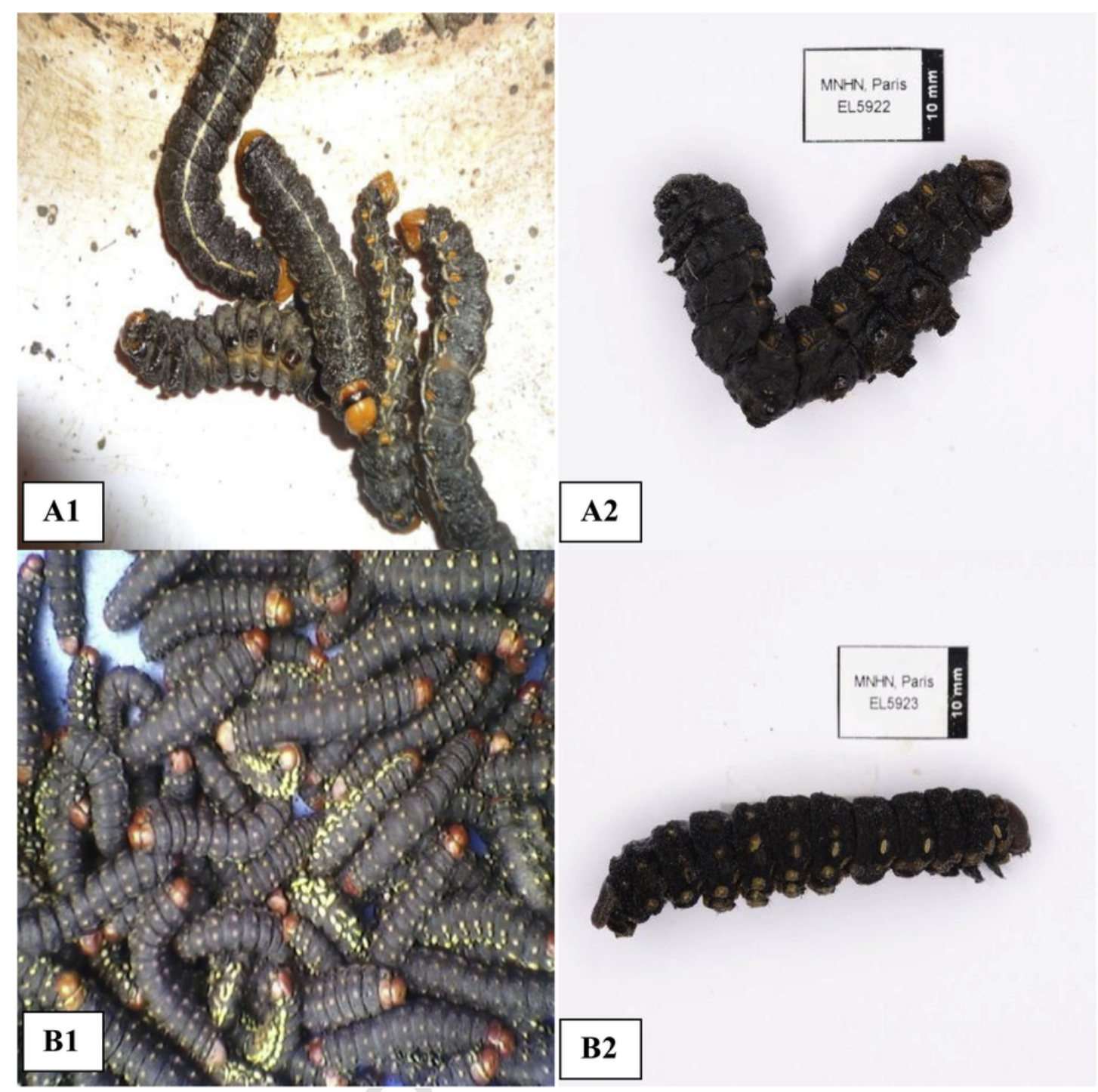

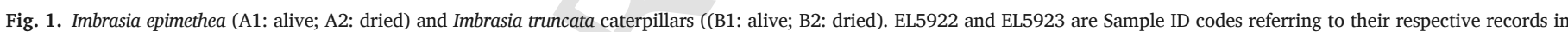
the Barcode of Life Datasystems (BOLD: www.boldsystems.org) dataset: DS-IMBR01 (https://doi.org/10.5883/ds-imbr01).

(HPLC grade), methanol absolute (HPLC Supra-Gradient), acetone (HPLC grade) were purchased from BiosolveChimie SARL (Dieuze, France). Cyclohexane (RS Plus for residual pesticide analysis) and ammonia (30\% solution for analysis ACS) were purchased from Carlo Erba Reagents SAS (Val de Reuil, France).

\subsection{Amino acid composition analysis}

Amino acid composition of the caterpillars flours were determined with an amino acid analyser (Hitachi high-speed amino acid analyser L8900, Hitachi, Japan), paired with anion exchange chromatography column (125 mm L $\times 4 \mathrm{~mm}$ ID; polystyrene-divinylbenzene copolymer as stationary phase : Li-Form, PEEK), and with a mobile phase consisting in 6 successive lithium acetate buffers with increasing $2.94-10.51 \mathrm{pHs}$. As previuously described (Fogang Mba et al., 2007; 2008), detection was performed after post-column derivatization by ninhydrin, at $570 \mathrm{~nm}$, except for proline at $440 \mathrm{~nm}$. Two internal standards (norleucine and glucosamic acid) were added to the flour before protein hydrolysis to allow quantification of amino acids. To recover and quantify all amino acids, including the most sensitive ones, we combined the results obtained after different conditions of protein hydrolysis: acid hydrolysis $\left(\mathrm{HCl} 6 \mathrm{~N}, 110^{\circ} \mathrm{C}\right)$ of $24 \mathrm{~h}$ to determine most amino acids, acid hydrolysis $\left(\mathrm{HCl} 6 \mathrm{~N}, 110^{\circ} \mathrm{C}\right)$ of $48 \mathrm{~h}$ to determined branched amino acids (Val, Leu and Ileu), acid hydrolysis after oxidation by performic acid for the determination of sulfur amino acids (Met and Cys), and alkaline hydrolysis $\left(\mathrm{Ba}(\mathrm{OH})_{2}, 4 \mathrm{~N}, 110^{\circ} \mathrm{C}, 16 \mathrm{~h}\right)$ for tryptophan determination. According to apparatus provider (Hitachi), the method specifications are: Reproducibily of Peak Area $=$ CV 1.0\% (Gly, His) and Detection Limit $=3 \mathrm{pmol}(\mathrm{S} / \mathrm{N}=2$, Asp). Individual amino acid residues and total amino acid residues concentrations were expressed in $\mathrm{mg} / \mathrm{g}$ protein and in $\mathrm{mg} / 100 \mathrm{~g}$ fresh weight. Indispensable amino acid scores were defined as the ratios of the contents in the insect proteins and in the reference protein for each essential amino acid (WHO/FAO/ UNU, 2007).

\subsection{Total nitrogen content, nitrogen to protein conversion factor and non protein nitrogen determination}

Total nitrogen content of the insect flours was determined using the Dumas method (Dumas, 1831) with an elemental analyser (Vario ISOTOPE Cube, Elementar, Frankfurt, Germany). To obtain nitrogen to protein conversion factors for Imbrasia species, their amount in total amino acid residueswere first calculated from amino acid composition (see parag. 2.3) and then divided by total nitrogen content (Dumas 
method) of the insect powders. Nitrogen content of total amino acid residues also calculated as the sum of nitrogen content of each amino acid residue. Non protein nitrogen was determined by subtracting mass of nitrogen of amino acid residues from total nitrogen content determined by Dumas method.

\subsection{Determination of water, ash, protein and lipid contents and of energetic value}

Water and ash contents of insect flours were assayed using the method of the Association of the Official Analytical Chemists(AOAC, 1996) and calculated as described previously (Fogang Mba et al., 2017). Protein content was determined by multiplying total nitrogen content with nitrogen to protein conversion factor, previously determined. Total lipidswere extracted from the raw thawed, eviscerated and ground insects according to Folch et al. (1957) with slight modifications as previously described (Fogang Mba et al., 2017). Water, ash, nitrogen and lipid contents were analysed at least in triplicate. Carbohydrates were determined by difference, according to the following formula:

Carbohydrates $_{\text {content in } \mathrm{g} / 100 \mathrm{~g}}=100-[$ (Protein + lipid + ash + moisture) content in $\mathrm{g} / 100 \mathrm{~g}]$.

Energy values were calculated using the Atwater coefficient: $16.2 \mathrm{~kJ}$ ( $4 \mathrm{kcal}) / \mathrm{g}$ for proteins and carbohydrates and $37.62 \mathrm{~kJ}(9 \mathrm{kcal}) / \mathrm{g}$ for lipids.

\subsection{Tocopherol analysis}

Tocopherol isomers ( $\alpha, \beta, \gamma$ and $\delta$ tocopherols) were identified and quantified in the total lipid extracts following AOCS Ce-8-89method (AOCS, 1998) with minor modifications (Fogang Mba et al., 2018). The compounds were identified by comparison of their retention time with that of authentic standards(tocopherol set 613424 , purity $\geq 95 \%$ ; Calbiochem, Merk Chimie, Fontenay-Sous-Bois, France; $\gamma$ tocotrienol, Ref. T0702, Sigma-Aldrich), also used for the external calibration. As previously stated, blank samples were run together with every sample series to check the column performance (Dionex Polar Advantage 2; $250 \mathrm{~mm} \times 3 \mathrm{~mm}$, 3umwithhexane/di-ter-butyl-ethyl ester (95/5; V/ $\mathrm{V})$ as mobile phase). The linear calibration curves for the different tocopherol isomers ( $\alpha, \beta, \gamma$ and $\delta$-tocopherol; 5-700 ng in n-hexane), obtained with a fluorescence detector (RF2000, Dionex; excitation; $295 \mathrm{~nm}$; emission: $330 \mathrm{~nm}$ ) wereperformed every day of analysis. The concentrations of the standard solutionswerepreviously checkedby the measurement of theirabsorbance at the maximum wavelength of each compound followed by concentration calculation by using their extinction coefficients. The calibration curves $\operatorname{hadR}^{2}>0.99$; and the method is characterized byLOD $\approx 5 \mathrm{ng}$; LOQ $<10 \mathrm{ng}$; RSD $<1.5 \%$ ). The results for each batch were means of triplicate measurementsmade on 3 lipidextracts and expressed as $\mathrm{mg}$ tocopherols per $100 \mathrm{~g}$ fresh weight.

\subsection{Fractionation of total lipids}

Total lipids (TL)were fractionatedby adsorption chromatographywitha column (height: $36 \mathrm{~cm}$; diameter: $2.5 \mathrm{~cm}$; volume: $176 \mathrm{~cm}^{3}$ ) packed with a mixture $(1 / 0.5 ; w / w)$ of powdered silicic acid(MP Silica 63-100, 60A, MP Biomedicals) and Celite 545 (Acros organics from Fisher Scientific)according to Kates (1972). The column was conditioned first with $50 \mathrm{ml}$ of methanoland then by $5 \mathrm{ml}$ of chloroform. Lipids (around $100 \mathrm{mg}$ dissolved in $1 \mathrm{mLchloroform}$ ) were then loaded onto the column.The neutral lipids (NL) were eluted with $150 \mathrm{ml}$ of chloroform, glycolipid + sulfolipid fraction (GL + SL) with $100 \mathrm{ml}$ of acetone and phospholipids (PL) with $100 \mathrm{ml}$ of methanol. The collected fractions were dried under a stream of nitrogen and weighted to obtain the mass of each fraction. Each fraction was then re-dissolved in chloroform and stored at $-20^{\circ} \mathrm{C}$ until further analysis.

\subsection{Determination of classes of neutral lipids and polar lipids}

Approximately $5 \mu \mathrm{g}$ of neutral lipid and polar lipid fractions in $10 \mu \mathrm{L}$ chloroform were analysed by high-performance liquid chromatography (HPLC) with a modular UltiMate 3000 RS system (Dionex, Voisins Le Bretonneux, France) equipped with an UptisphereStrategy column (150 mm $\times 4.6 \mathrm{~mm}, 2.2 \mu \mathrm{m}, 100 \AA$; Interchim, Montluçon, France) and coupled to an evaporative light scattering detector (ELSD) Sedex 85(Sedere S.A., Alfortville, France). Chromatographic conditions, identification and quantification of neutral lipids and phospholipids were described previously (Fogang Mba et al., 2017). Lipid classes were identified bycomparison of their retention times to those of lipid standards and theirconcentrations calculated by the use of calibration curves (range concentrations)obtained witheach standard. Triolein, diolein, mono-olein, oleic acid, phosphatidyl-choline(PC), phosphatidyl-ethanolamine (PE), phosphatidyl-serine (PS),phosphatidy-linositol (PI), sphingomyelin (SPH) lyso-phosphatidyl-choline(LPC) were purchased from Sigma-Aldrich (Saint-QuentinFallavier, France).

\subsection{Fatty acid composition of total lipids and main lipid fractions}

Fatty acid compositions of total lipids were determined after transmethylation of $1 \mathrm{mg}$ lipid with $\mathrm{BF}_{3} / \mathrm{CH}_{3} \mathrm{OH} 14 \%$ in presence of an internal standard (C17:0),according to Morrison and Smith (1964). Fatty acid methyl esters (FAMEs) analysis was performed on agas chromatograph (Clarus ${ }^{\circledR} 680$ GC, Perkin Elmer, Courtaboeuf, France) paired with a splitless injector and a flame ionization detector, and equipped with an HP 225 column $(30 \mathrm{~m} \times 0.25 \mathrm{~mm}$, film thickness $0.25 \mu \mathrm{m}$, J\&W Scientific, Chromoptic, Auxerre, France). Chromatographic conditions for fatty acid separation and their identification were performed as described previously (Fogang Mba et al., 2017, 2018). Individual fatty acids were identified by comparison of their retention times with those of standards (FAMEmix; Supelco, SigmaSaint Quentin Fallavier, France).Any loss of the separation capacity of the column was controlled on the chromatograms obtained with the fatty acid standards. Blank samples (n-hexane) were also injected every day to check the column performance. Results were expressed as percentage of each fatty acid (FA) to the total identified fatty acids (TFA) (g/100 g TFA) and in mg. $\mathrm{g}^{-1}$ lipids and in $\mathrm{g} / 100 \mathrm{~g}$ fresh weight. Limit of detection (amount of FA resulting in a peak with a height three times that of the baseline noise) was around $0.01 \mathrm{~g} / 100 \mathrm{~g}$ total FA or $0.01 \mathrm{mg} / 100 \mathrm{~g}$ FW.

\subsection{Data analysis}

Except amino acid determination $(\mathrm{n}=1)$, all analyses were performed in triplicates $(n=3)$. Results were expressed as the means \pm standard deviations. Data were transformed with ARCSIN function in Excel 2007. The student $t$-test was used to compare significant difference between means at $0.05 \%$ probability level. Software GraphPad Prism 7.0 (GraphPad Software, San Diego, USA) was used for statistical analysis.

\section{Results}

\subsection{Identification of the insects}

Morphological identification of the larvae of the two Emperor moths butterfly was done from 10 individuals of each insect type whose morphologic criteria were compared to the descriptions made 
by Mabossy-mobouna et al. (2017) and Mabossy-Mobouna et al. (2016). The insects presented morphological characteristics typical of $I$. truncata and I. epimethea respectively (Fig. 1) (Mabossy-Mobouna et al., 2013; Rougerie and Estradel, 2008). The insects identified as Imbrasia truncata (Fig. 1, B1 \&B2) had a mean weight of $7.20 \pm 0.96 \mathrm{~g}$ with a maximum weight of $9.51 \mathrm{~g}$ and a minimum weight of $5.98 \mathrm{~g}$. The second species, identified as $I$. epimethea had a mean weight of $6.06 \pm 1.25 \mathrm{~g}$ with a maximum weight of $7.81 \mathrm{~g}$ and a minimum weight of $4.21 \mathrm{~g}$.

The comparison of DNA barcode sequences obtained fromtwo caterpillars belonging to the two morphologically recognized species confirmed unequivocally the identifications. The sequence of sample EL5922 matched with 100\% similarity sequences for several records of I. epimethea on BOLD. There are actually 13 public records in BOLD for this species, all part of a cohesive genetic cluster registered as Barcode Index Number (BIN, see Ratnasingham and Hebert (2013)) BOLD:AAA8454. This BIN (http://v4.boldsystems.org/index.php/ Public_BarcodeCluster?clusteruri = BOLD:AAA8454) gathers 67 records on BOLD, with an average genetic distance of $0.39 \%$ (uncorrected p-distance as displayed on BOLD), a maximum distance of $2.45 \%$, and a minimum distance to nearest neighbour of $7.3 \%$ with its relative $I$. ertli Rebel, 1904.

Similarly, the sequence of EL5923 matched with 100\% similarity the DNA barcodes of several records of $I$. truncata on BOLD. This species is represented by 9 public records on BOLD, all grouped in a single genetic cluster (BOLD:AAD8560; http://v4.boldsystems.org/index.php/Public BarcodeCluster?clusteruri=BOLD:AAD8560), with an average genetic distance of $0.65 \%$, a maximum distance of $1.38 \%$, and a minimum distance to nearest neighbour of $4.3 \%$ with $I$. ertli.

\subsection{Amino acid composition}

Amino acid compositions of Imbrasia truncata and I. epimethea larvae are presented in Table 1. Eighteen amino acids were quantified in the two insects, including all of the indispensable amino acids (IAAs), even tryptophan. Glutamic acid was the major amino acid present in I. truncata (2772 mg/100 g FW) and I. epimethea (2789 mg/100 g FW). Indispensable amino acids represented $53.7 \mathrm{~g} / 100 \mathrm{~g}$ of total amino acids (TAA) $(10228 \mathrm{mg} / 100 \mathrm{~g} \mathrm{FW})$ in $I$. truncata and $51.3 \mathrm{~g} / 100 \mathrm{~g}$ TAA $(10310 \mathrm{mg} / 100 \mathrm{~g}$ FW) in I. epimethea.

\subsection{Nitrogen to protein conversion factors and non-protein nitrogen}

Nitrogen to protein conversions factors and non-protein nitrogen of Imbrasia truncata and I. epimethea larvae are presented in Table 2.Nitrogen to protein conversion factors equal to $6.01 \pm 0.21$ and $6.27 \pm 0.15$ were found for Imbrasia truncata and Imbrasia epimethea, respectively (Table 1). Non protein nitrogen represented $2.2 \mathrm{~g} / 100 \mathrm{~g}$ total nitrogen in I. epimethea and $7.9 \mathrm{~g} / 100 \mathrm{~g}$ total nitrogen in $I$. truncata.

\subsection{Proximate composition}

The proximate composition of Imbrasia truncata and I. epimethea larvae is presented in Table 3 . The two insect species exhibited significantly similar water, protein and lipid contents $(p>0.05)$ but differed slightly but significantly in ash content $(\mathrm{p}<0.05)$. Water content represented about $70.2(69.7$; 70.7) $\mathrm{g} / 100 \mathrm{~g}$ fresh weight (FW) while proteins represented about $19.6(19.1 ; 20.1) \mathrm{g} / 100 \mathrm{~g}$ FW; total lipid content represented around $6.8(6.8 ; 6.7) \mathrm{g} / 100 \mathrm{~g}$ FW. Energy contents of $I$. truncata and I. epimethealarvae were also close: $633.0 \mathrm{~kJ} / 100 \mathrm{~g} \mathrm{FW}$ and $614.3 \mathrm{~kJ} /$ $100 \mathrm{~g}$ FW respectively.
Table 1

Amino acid content of Imbrasia truncata and Imbrasia epimethea caterpillars and comparison with other protein sources and $\mathrm{FAO} / \mathrm{WHO} / \mathrm{UNU}$ nutritional recommendations.

\begin{tabular}{|c|c|c|c|c|c|c|}
\hline $\begin{array}{l}\text { Imbrasia } \\
\text { truncata }\end{array}$ & $\begin{array}{l}\text { Imbrasia } \\
\text { epimetheo }\end{array}$ & & $\begin{array}{l}\text { Fish } \\
\text { (flesh)(1) }\end{array}$ & $\begin{array}{l}\text { Beef } \\
\text { and } \\
\text { veal (1) }\end{array}$ & $\begin{array}{l}\text { Chicken } \\
(\text { flesh)(1) }\end{array}$ & $\begin{array}{l}\text { WHI } \\
\text { RV } \\
(2)\end{array}$ \\
\hline & \multicolumn{3}{|c|}{ (mg/100 g fresh weight) } & & & \\
\hline ALA & 716 & 930 & 1126 & 1033 & 682 & \\
\hline ARG & 971 & 1100 & 1066 & 1118 & 1114 & \\
\hline ASP & 1668 & 2029 & 1947 & 1590 & 1834 & \\
\hline GLU & 2772 & 2789 & 2655 & 2703 & 3002 & \\
\hline GLY & 840 & 858 & 906 & 860 & 1059 & \\
\hline PRO & 1018 & 1098 & 692 & 628 & 829 & \\
\hline SER & 834 & 970 & 816 & 713 & 781 & \\
\hline Total NIAA & 8819 & 9773 & & & & \\
\hline HIS & 666 & 685 & 665 & 603 & 525 & 690 \\
\hline ILE & 809 & 865 & 900 & 852 & 1069 & 1380 \\
\hline LEU & 1148 & 1250 & 1445 & 1435 & 1472 & 1794 \\
\hline LYS & 1449 & 1479 & 1713 & 1573 & 1590 & 2070 \\
\hline THR & 1036 & 1207 & 861 & 812 & 794 & 1058 \\
\hline VAL & 864 & 1049 & 1150 & 886 & 1018 & 1794 \\
\hline PHE & 799 & 1114 & 737 & 778 & 800 & \\
\hline TRP & 245 & 266 & & & 205 & 276 \\
\hline TYR & 2647 & 1821 & 689 & 637 & 669 & \\
\hline AAA & 3692 & 3201 & 1426 & 1415 & 1469 & 1748 \\
\hline CYS & 237 & 205 & 220 & 226 & 262 & \\
\hline MET & 326 & 370 & 539 & 478 & 502 & \\
\hline SAA & 564 & 575 & 759 & 704 & 764 & 1012 \\
\hline Total IAA & 10228 & 10310 & 8919 & 8280 & 8906 & 9062 \\
\hline $\begin{array}{l}\text { Total AA } \\
\text { residues }\end{array}$ & 19047 & 20082 & 18338 & 17163 & 18206 & \\
\hline
\end{tabular}

AA: amino acids; IAA: indispensable amino acids; NIAA: non indispensable amino acids; AAA: aromatic amino acid (Phe + Tyr + Trp); *SAA: sulfur amino acid (Met + Cys); FAO: Food and Agriculture Organisation, WHO: World Health Organization; UNU: United Nation University.

(1) : (FAO, 1970); (2) : WHO RV: World Health Organization Reference Values (WHO, 2007) for the daily amino acid requirements of a $55 \mathrm{~kg}$ woman consuming $46 \mathrm{~g}$ of protein per day.

Table 2

Nitrogen (Dumas method) to protein conversion factors for Imbrasia truncata and Imbrasia epimethea caterpillars.

\begin{tabular}{|c|c|c|c|c|c|c|}
\hline & $\begin{array}{l}\text { TAAR } \\
(\mathrm{g} / \\
100 \mathrm{~g} \\
\text { FW) }\end{array}$ & $\begin{array}{l}N(g / 100 g \\
\text { FW) }\end{array}$ & $\mathrm{CF}$ & $\begin{array}{l}\text { Nitrogen } \\
\text { in TAAR } \\
(\mathrm{g} / 100 \mathrm{~g} \\
\text { FW) }\end{array}$ & $\begin{array}{l}\% \mathrm{PN} \\
(\mathrm{g} / \\
100 \mathrm{~g} \mathrm{~N})\end{array}$ & $\begin{array}{l}\% \\
(g \\
10\end{array}$ \\
\hline $\begin{array}{l}\text { Imbrasia } \\
\text { truncata }\end{array}$ & 19.05 & $3.17 \pm 0.11$ & $6.01 \pm 0.21$ & 2.92 & 92.11 & 7.8 \\
\hline $\begin{array}{l}\text { Imbrasia } \\
\text { epimethea }\end{array}$ & 20.08 & $3.20 \pm 0.08$ & $6.27 \pm 0,15$ & 3.13 & 97.78 & \\
\hline
\end{tabular}

Value presented in the table is mean \pm s.d.

$\mathrm{CF}$ : conversion factor; FW: fresh weight; $\mathrm{N}$ : total nitrogen (Dumas method); NPN: non-protein nitrogen; PN: protein nitrogen; TAAR: total amino acid residues.

\subsection{Vitamin $E$ composition ( $\alpha, \beta, \gamma$ and $\delta$ tocopherols)}

Total tocopherol content was higher $(\mathrm{p}<0.05)$ in Imbrasia truncata larvae: $119.7 \pm 16.5 \mu \mathrm{g} / \mathrm{g}$ lipids $(0.82 \pm 0.11 \mathrm{mg} / 100 \mathrm{~g} \mathrm{FW})$ than in Imbrasia epimethea larvae: $224.4 \pm 22.5 \mu \mathrm{g} / \mathrm{g}$ lipids $(1.50 \pm 0.15 \mathrm{mg} /$ $100 \mathrm{~g} \mathrm{FW}$ ) (Table 4). $\alpha$-tocopherol was the major tocopherol isomer in $I$. truncata (76.6 $\pm 11.2 \mu \mathrm{g} / \mathrm{g}$ lipids)while $\gamma$-tocopherol was major in I. epimethea (about $150 \mu \mathrm{g} / \mathrm{g}$ lipids), both accompanied by the other $(\alpha, \beta, \gamma, \delta)$ isomers. $\alpha$-Tocopherol supplied by $100 \mathrm{~g}$ of $I$. truncata is $0.52 \pm 0.08 \mathrm{mg}$ and $0.41 \pm 0.06 \mathrm{mg}$ by $100 \mathrm{~g}$ of $\mathrm{I}$. epimethea larvae. 
Table 3

: Proximate composition of Imbrasia truncata and Imbrasia epimethea caterpillars ( $\mathrm{n}=3$ ).

\begin{tabular}{|c|c|c|c|c|c|c|}
\hline & Water & Total lipids & Proteins & Carbohydrates* & Ash & Energy $(\mathrm{kJ} / \mathrm{kcal})$ \\
\hline Fresh weight $(\mathrm{g} / 100 \mathrm{~g} F W)$ Imbrasia truncata & $69.7 \pm 1.5$ & $6.8 \pm 0.6$ & $19.1 \pm 0.7$ & 3.4 & $1.03 \pm 0,01^{\mathrm{A}}$ & $633.0(151.3)$ \\
\hline Imbrasia epimethea & $70.7 \pm 0.9$ & $6.7 \pm 0.2$ & $20.1 \pm 0.5$ & 0.9 & $0.97 \pm 0,01^{\mathrm{B}}$ & $613.3(146.6)$ \\
\hline Dry weight ( $\mathrm{g} / 100 \mathrm{~g} \mathrm{DW}$ ) Imbrasia truncata & / & $22.6 \pm 2.1$ & $62.9 \pm 2.1^{\mathrm{B}}$ & 11.1 & $3.41 \pm 0,03^{\mathrm{A}}$ & $2088.7(499.1)$ \\
\hline Imbrasia epimethea & / & $22.8 \pm 0.8$ & $68.6 \pm 1.6^{\mathrm{A}}$ & 5.3 & $3.32 \pm 0,04^{\mathrm{B}}$ & $2094.6(500.6)$ \\
\hline
\end{tabular}

Value presented in the table is mean \pm s.d.

": by difference (Cabohydrates ${ }_{\mathrm{g} / 100 \mathrm{~g} \mathrm{FW}}=100-[\text { Proteins }+ \text { lipids }+ \text { ash }+ \text { water }]_{\mathrm{g} / 100 \mathrm{~g} \mathrm{FW}}$ );

For a given proximate compound, means with different capital letter within a colunm are significantly different $(\mathrm{p}<0.05)$.

FW: fresh weight; DW: Dry weight.

Table 4

Tocopherol composition in Imbrasia truncata and Imbrasia epimethea larvae $(\mathrm{n}=3)$.

\begin{tabular}{|c|c|c|c|}
\hline & $\begin{array}{l}\text { Imbrasia } \\
\text { truncata }\end{array}$ & $\begin{array}{l}\text { Imbrasia } \\
\text { epimethea }\end{array}$ & $\begin{array}{l}\text { DRI*(mg/ } \\
\text { Day) }\end{array}$ \\
\hline$\alpha$-tocopherol ( $\mu \mathrm{g} / \mathrm{g}$ lipids) & $76.6 \pm 11.2$ & $62.1 \pm 9.0$ & \\
\hline$\beta$-tocopherol ( $\mu \mathrm{g} / \mathrm{g}$ lipids) & $10.9 \pm 2.3^{\mathrm{A}}$ & $3.3 \pm 1.0^{\mathrm{B}}$ & \\
\hline$\gamma$-tocopherol ( $\mu \mathrm{g} / \mathrm{g}$ lipids) & $21.9 \pm 3.3^{\mathrm{A}}$ & $149.7 \pm 12.1^{\mathrm{B}}$ & \\
\hline$\delta$-tocopherol ( $\mu \mathrm{g} / \mathrm{g}$ lipids) & $10.4 \pm 1.1$ & $9.2 \pm 0.8$ & \\
\hline $\begin{array}{l}\text { Total tocopherol }(\mu \mathrm{g} / \mathrm{g} \\
\text { lipids) }\end{array}$ & $119.7 \pm 16.5^{\mathrm{A}}$ & $224.4 \pm 22.5^{\mathrm{B}}$ & \\
\hline $\begin{array}{l}\alpha \text {-tocopherol (mg/100 g } \\
\text { FW) }\end{array}$ & $0.52 \pm 0.08$ & $0.41 \pm 0.06$ & $12-15$ \\
\hline $\begin{array}{l}\text { B-tocopherol ((mg/100 g } \\
\text { FW) }\end{array}$ & $0.07 \pm 0.02^{\mathrm{A}}$ & $0.02 \pm 0.01^{\mathrm{B}}$ & \\
\hline $\begin{array}{l}\gamma \text {-tocopherol (mg/100 g } \\
\text { FW) }\end{array}$ & $0.15 \pm 0.02^{\mathrm{A}}$ & $1.00 \pm 0.08^{\mathrm{B}}$ & \\
\hline $\begin{array}{l}\delta \text {-tocopherol (mg/100 g } \\
\text { FW) }\end{array}$ & $0.07 \pm 0.01$ & $0.06 \pm 0.01$ & \\
\hline $\begin{array}{l}\text { Total tocopherol (mg/ } \\
100 \mathrm{~g} \mathrm{FW)}\end{array}$ & $0.82 \pm 0.11^{\mathrm{A}}$ & $1.50 \pm 0.15^{\mathrm{B}}$ & \\
\hline
\end{tabular}

Value presented in the table is mean \pm s.d.

FW: Fresh weight; DRI*: Dietary Reference Intake for an adult, (FAO, 2001).

For a given tocopherol isomer, means with different capital letter within a row are significantly different $(\mathrm{p}<0.05)$.

\subsection{Lipid fractions}

The proportions of main lipid fractions in $I$. truncata and $I$. epimetheatotal lipids are presented in Table 5. For both insects, neutral lipid (NL) fraction was by far the major fraction:96.2 $\pm 0.2 \mathrm{~g} / 100 \mathrm{~g}$ lipids for $I$. truncata; and $94.1 \pm 1.1 \mathrm{~g} / 100 \mathrm{~g}$ lipids for $I$. epimethea. In I. truncata, the fraction eluted by acetone (glycolipid (GL) + sulfolipid fraction (SL)) accounted for $2.3 \pm 0.4 \mathrm{~g} / 100 \mathrm{~g}$ lipids and phospholipids (PL) $1.5 \pm 0.2 \mathrm{~g} / 100 \mathrm{~g}$ lipids. In I. epimethea, GL + SL fraction represented $3.3 \pm 0.9 \mathrm{~g} / 100 \mathrm{~g}$ lipids and PL $2.7 \pm 0.3 \mathrm{~g} / 100 \mathrm{~g}$ lipid.

\subsection{Composition of the lipid fractions}

The neutral lipids we recovered first from the total lipids extracts from I. truncata and I. epimethea larvae were almost exclusively com-

Table 5

Lipid fractions in total lipids of Imbrasia truncata and Imbrasia epimethea caterpillars $(\mathrm{n}=3)$.

\begin{tabular}{llll}
\hline Insect type & Neutral lipids & Acetone-eluted fraction & Phospholipids \\
\hline & g/100 g total lipids & \\
Imbrasia truncata & $96.2 \pm 0.2^{\mathrm{A}}$ & $2.3 \pm 0.4$ & $1.5 \pm 0.2^{\mathrm{A}}$ \\
Imbrasia epimethea & $94.1 \pm 1.1^{\mathrm{B}}$ & $3.3 \pm 0.9$ & $2.7 \pm 0.3^{\mathrm{B}}$ \\
\hline
\end{tabular}

Value presented in the table is mean \pm s.d.

For a given lipid fraction, means with different capital letter within column are significantly different for the two Imbrasia species $(\mathrm{p}<0.05$ ). posed of free fatty acids as found on HPLC chromatograms of the fraction (Supplementary data, Figure A). This result suggested that the glycerolipids initially present in the living Imbrasia caterpillars were hydrolyzed during the steps that separated insects sampling to lipid extraction: freezing followed by storage at freezing temperature, thawing, evisceration and mincing. To verify this hypothesis, living caterpillars of the two Imbrasia species were frozen and then boiled during $15 \mathrm{~min}$, to inactivate lipolytic enzymes. The insects were then eviscerated, grounded and finally kept frozen $\left(-18^{\circ} \mathrm{C}\right)$ until lipid extraction and fractionation. The neutral lipid fraction of these boiled I. epimethea larvae contained $43.5 \%$ of triglycerides and $56.5 \%$ of free fatty acids (Supplementary data, Fig. B). This result confirms that glycerolipids were present in the body of the living animals and that hydrolysis of lipids took place when the enzymes had not previously been denaturated. In contrast, the hydrolysis was partly inhibited by the thermal treatment. However, this treatment took place after a first step of freezing. Lipolytic enzymes, probably very active in the body of these caterpillars, are known to remain active at low temperature. Thus, they already had hydrolyzed a large fraction of the triacylglycerols during the first frozen storage step, explaining the free fatty acid level in the boiled I. epimethea larvae. Accordingly, the neutral lipid fraction of the boiled then frozen $I$. truncata still contained $99.46 \%$ of free fatty acids and only $0.54 \%$ of triglycerides.

Phospholipid compositions of freeze, thawed and eviscerated I. truncata and I. epimethea are presented in Table 6. Interestingly, for both insects, the major phospholipid class was sphingomyelin with the highest level in I. epimethea(71.0 $\pm 9.3 \mathrm{~g} / 100 \mathrm{~g}$ phospholipids). Phosphatidylcholine was the second major phospholipid, and the highest level was found in $I$. truncata $(25.5 \pm 1.5 \mathrm{~g} / 100 \mathrm{~g}$ phospholipids). Apart from phosphatidylcholine whom contents were statistically different in both insects, all the other classes of phospholipids were present at similar percentages in I. truncata and I. epimethea. Little content of lysophospholipids ( $<9 \mathrm{~g} / 100 \mathrm{~g}$ phospholipids) was found in the insects.

Table 6

: Phospholipid classes of Imbrasia epimethea and Imbrasia truncata caterpillars (g/100 g phospholipids; $\mathrm{n}=3$ ).

\begin{tabular}{lll}
\hline $\mathrm{g} / 100 \mathrm{~g}$ PL & Imbrasia truncata & Imbrasia epimethea \\
\hline $\mathrm{PE}$ & $7.5 \pm 1.7$ & $6.7 \pm 1.1$ \\
$\mathrm{LPE}+\mathrm{PI}$ & $2.9 \pm 0.2$ & $3.3 \pm 0.9$ \\
$\mathrm{PC}$ & $25.5 \pm 1.5^{\mathrm{A}}$ & $13.4 \pm 4.6^{\mathrm{B}}$ \\
$\mathrm{SPH}$ & $61.8 \pm 2.2$ & $71.0 \pm 9.3$ \\
$\mathrm{LPC}$ & $2.3 \pm 1.1$ & $5.6 \pm 6.2$ \\
\hline
\end{tabular}

Value presented in the table is mean \pm s.d.

PE: phosphatidyl-ethanolamine; LPE: lyso-phosphatidyl-ethanolamine; PS: phosphatidyl-serine; PI: phosphatidyl-inositol; PC: phosphatidyl-choline; SPH: sphingomyelin; LPC: lyso-phosphatidyl-choline.

For a given phospholipid class, means with different capital letter within a line are significantly different for the two Imbrasia species $(\mathrm{p}<0.05)$. 


\subsection{Fatty acid amounts of total lipids and lipid fractions}

Fatty acid (FA) contents (mg/100 g FW) of $I$. truncata and I. epimethea larvae are shown in Table 7 and fatty acid composition of total lipids and lipid fractions (g FA/100 lipids) are presented in supplementary data (Table B).Thirteen fatty acids have been identified in $I$. truncata and fourteen in I. epimethea. These insects have fairly high levels of unsaturated fatty acids (UFA): $2633 \pm 205 \mathrm{mg} / 100 \mathrm{~g}$ FW in $I$. truncata and $3243 \pm 214 \mathrm{mg} / 100 \mathrm{~g}$ FWin I. epimethea. Three polyunsaturated fatty acids (PUFAs) were identified in total lipids of both insects (18:2n-6, 18:3n-3 and 20:3n-3). The highest level of PUFAs was obtained in $I$. epimethea $(2778 \pm 194 \mathrm{mg} / 100 \mathrm{~g} \mathrm{FW})$ and the lowest in I. truncata(2183 $\pm 171 \mathrm{~g} / 100 \mathrm{~g} \mathrm{FW})$. Alpha-linolenic acid (C18:3n-3) was by far the major fatty acid. It represented $1883 \pm 146 \mathrm{mg} / 100 \mathrm{~g}$ FW in $I$. truncata and $2170 \pm 131 \mathrm{mg} / 100 \mathrm{~g} \mathrm{FW}$ in $I$. epimethea. Saturated fatty acids represented from $1846 \pm 157 \mathrm{mg} / 100 \mathrm{~g}$ FW (I. truncata) to $1778 \pm 189 \mathrm{mg} / 100 \mathrm{~g}$ FW (I.epimethea), mainly in the form of palmitic acid (C16: 798-1099 mg/100 g FW) followed by stearic acid (C18:710 - $941 \mathrm{mg} / 100 \mathrm{~g} \mathrm{FW}$ ).Total fatty acid content was similar in I. truncata $(4480 \pm 361 \mathrm{mg} / 100 \mathrm{~g} \quad \mathrm{FW})$ an in $I$. epimethea $(5022 \pm 26 \mathrm{mg} / 100 \mathrm{~g} \mathrm{FW})$. Only a small part of fatty acids were carried by polar lipids (Table 7).

Fatty acid composition of lipid fractions of Imbrasia truncata and $I$. epimethea are shown in Table B (Supplementary data). Fatty acid compositions of neutral lipid of $I$. truncata and I. epimethea caterpillars were similar to the compositions of total lipids. In contrast, the fatty acid compositions of PL of the two insects were strongly different from their neutral lipids and total lipid compositions. PL contained more saturated fatty acids than total and neutral lipids and within SFA, less C16, more C18 and C20 with the presence at minor levels of C22, 23 and C24 which were not detected in total and neutral lipids. PL also contained more 18:2 n- 6 but less18:3 n-3 especially in I. truncataand globally less PUFA than total and neutral lipids.PL also contained small amounts of arachidonic acid (C20:4 n-6) while C20:3 n-3, present in total and neutral lipids was not detected in this fraction. Some differences were also observed in the FA compositions of the PL of the two insect species. The fatty acids C15 and C17:1 were absent in I. truncata and present in I. epimethea. Fatty acid compositions of the fractions eluted by acetone (GL + SL) differed also strongly from the fatty acid compositions of the NL and PL fractions. Major FA class in this fraction was PUFA with different contents in I. truncata $(39.54 \pm 2.66 \mathrm{~g} / 100 \mathrm{~g} \mathrm{FA})$ and I. epimethea (43.47 $\pm 1.03 \mathrm{~g} / 100 \mathrm{~g}$ FA) (Supplementary data, Table B).

\section{Discussion}

\subsection{Emperor moths (Imbrasia sp.) caterpillars could represent a good source of proteins and indispensable amino acids}

Proteins contents of $I$. truncata and $I$. epimethea were in the range already reported for Imbrasia species (Akpossan et al., 2014; Kwiri et al., 2014; Bukkens, 1997; Mabossy-mobouna et al., 2017). As the lower limit for the food label 'high in protein' is $10 \mathrm{~g} / 100 \mathrm{~g}$ edible portion (EP) (Nowak et al., 2016), I. truncata and I. epimethea larvae, with approximately $20 \mathrm{~g}$ protein $/ 100 \mathrm{~g}$ fresh weight, can be considered as high in protein. As the reference intake (PRI) of protein is estimated to be $0.83 \mathrm{~g}$ protein $/ \mathrm{kg}$ body weight per day for an healthy adult(EFSA, 2012), that is62.25 $\mathrm{g}$ of protein daily for an adult of $75 \mathrm{~kg}$, the consumption of a serving size (20 insects) of I. truncata (144 g) or I. epimethea caterpillars ( $121 \mathrm{~g}$ ) will represent respectively $44.2 \%$ and $39.1 \%$ of protein daily reference intake. Other nutritional interest of insects is the amino acid composition of their proteins which in most

Table 7

Fatty acid amounts (mg/100 g FW) contained in main lipid fractions of Imbrasia truncata and Imbrasia epimethea larvae (n = 3)

\begin{tabular}{|c|c|c|c|c|c|c|c|c|}
\hline & \multicolumn{2}{|l|}{ Total lipids } & \multicolumn{2}{|l|}{ Neutral lipids } & \multicolumn{2}{|c|}{ Acetone-soluble fraction } & \multicolumn{2}{|l|}{ Phospholipids } \\
\hline & I. truncata & I. epimethea & I. truncata & I. epimethea & I. truncata & I. epimethea & I. truncata & I. epimethea \\
\hline $\mathrm{C} 14$ & $18.1 \pm 1.9^{\mathrm{A}}$ & $11.0 \pm 3.5^{\mathrm{B}}$ & $20.0 \pm 0.2^{\mathrm{A}}$ & $12.1 \pm 1.3^{\mathrm{B}}$ & $0.11 \pm 0.01^{\mathrm{A}}$ & $0.14 \pm 0.03^{\mathrm{A}}$ & $0.04 \pm 0.00^{\mathrm{A}}$ & $0.07 \pm 0.01^{\mathrm{B}}$ \\
\hline $\mathrm{C} 15$ & $9.6 \pm 0.9^{\mathrm{A}}$ & $8.7 \pm 0.3^{\mathrm{A}}$ & $10.6 \pm 0.2^{\mathrm{A}}$ & $7.9 \pm 0.5^{\mathrm{B}}$ & $0.05 \pm 0.00^{\mathrm{A}}$ & $0.08 \pm 0.02^{\mathrm{A}}$ & nd & $0.08 \pm 0.01$ \\
\hline $\mathrm{C} 16$ & $1099 \pm 95^{\mathrm{A}}$ & $798 \pm 63^{\mathrm{B}}$ & $1248 \pm 31^{\mathrm{A}}$ & $678 \pm 48^{B}$ & $4.7 \pm 0.3^{\mathrm{A}}$ & $5.03 \pm 0.13^{\mathrm{A}}$ & $0.90 \pm 0.07^{\mathrm{A}}$ & $1.07 \pm 0.09^{\mathrm{A}}$ \\
\hline $\mathrm{C} 18$ & $710 \pm 60^{\mathrm{B}}$ & $941 \pm 121^{\mathrm{A}}$ & $823 \pm 28^{\mathrm{A}}$ & $828 \pm 54^{\mathrm{A}}$ & $2.7 \pm 0.1^{\mathrm{B}}$ & $5.06 \pm 0.21^{\mathrm{A}}$ & $1.73 \pm 0.03^{\mathrm{B}}$ & $2.96 \pm 0.20^{\mathrm{A}}$ \\
\hline $\mathrm{C} 20$ & $9.6 \pm 1.7^{\mathrm{B}}$ & $20.1 \pm 3.1^{\mathrm{A}}$ & $11.9 \pm 1.1^{\mathrm{B}}$ & $16.6 \pm 0.3^{\mathrm{A}}$ & $0.11 \pm 0.00^{\mathrm{A}}$ & $0.17 \pm 0.05^{\mathrm{A}}$ & $1.12 \pm 0.03^{\mathrm{B}}$ & $2.62 \pm 0.10^{\mathrm{A}}$ \\
\hline $\mathrm{C} 22$ & nd & nd & nd & nd & $0,08 \pm 0,00^{\mathrm{A}}$ & $0,09 \pm 0,03^{\mathrm{A}}$ & $1,52 \pm 0,05^{\mathrm{B}}$ & $2,89 \pm 0,01^{\mathrm{A}}$ \\
\hline $\mathrm{C} 23$ & nd & nd & nd & nd & nd & nd & $0,12 \pm 0,00^{\mathrm{A}}$ & $0,13 \pm 0,01^{\mathrm{A}}$ \\
\hline $\mathrm{C} 24$ & nd & nd & nd & nd & nd & nd & $0,13 \pm 0,02^{\mathrm{B}}$ & $0,24 \pm 0,02^{\mathrm{A}}$ \\
\hline C16:1n-9 & $2.6 \pm 4.5^{A}$ & $6.3 \pm 0.4^{A}$ & $7.7 \pm 0.1^{B}$ & $12.5 \pm 1.1^{\mathrm{A}}$ & $0.03 \pm 0.02^{\mathrm{A}}$ & $0.05 \pm 0.01^{\mathrm{A}}$ & $0.03 \pm 0.01^{\mathrm{A}}$ & $0.06 \pm 0.02^{\mathrm{A}}$ \\
\hline $\mathrm{C} 16: 1 \mathrm{n}-7$ & $31 \pm 3^{\mathrm{A}}$ & $16 \pm 1^{\mathrm{B}}$ & $28 \pm 6^{\mathrm{A}}$ & $0.0 \pm 0.0^{\mathrm{B}}$ & $0.19 \pm 0.03^{\mathrm{A}}$ & $0.14 \pm 0.01^{\mathrm{A}}$ & $0.03 \pm 0.00^{\mathrm{B}}$ & $0.06 \pm 0.00^{\mathrm{A}}$ \\
\hline c17:1 & $7.0 \pm 0.4^{\mathrm{A}}$ & $7.0 \pm 0.1^{\mathrm{A}}$ & $8.6 \pm 0.1$ & $\operatorname{tr}$ & $0.0 \pm 0.0^{\mathrm{A}}$ & $0.01 \pm 0.02^{\mathrm{A}}$ & nd & $0.16 \pm 0.03$ \\
\hline C18:1n-9 & $385 \pm 28^{A}$ & $407 \pm 22^{\mathrm{A}}$ & $446 \pm 16^{A}$ & $323 \pm 17^{\mathrm{B}}$ & $1.12 \pm 0.05^{\mathrm{B}}$ & $1.56 \pm 0.03^{\mathrm{A}}$ & $0.55 \pm 0.06^{\mathrm{B}}$ & $0.85 \pm 0.04^{\mathrm{A}}$ \\
\hline C18:1n-7 & $25 \pm 2^{\mathrm{A}}$ & $18 \pm 1^{\mathrm{A}}$ & $29 \pm 1^{\mathrm{A}}$ & $14 \pm 1^{\mathrm{B}}$ & $0.08 \pm 0.00^{\mathrm{A}}$ & $0.06 \pm 0.01^{\mathrm{A}}$ & $0.04 \pm 0.01^{\mathrm{A}}$ & $0.04 \pm 0.01^{\mathrm{A}}$ \\
\hline C20:1n-9 & nd & $11.5 \pm 5.2$ & nd & $8.7 \pm 0.7$ & $0.06 \pm 0.02^{\mathrm{A}}$ & $0.07 \pm 0.03^{\mathrm{A}}$ & nd & nd \\
\hline C22:1n-9 & nd & nd & nd & nd & $0.12 \pm 0.03^{\mathrm{A}}$ & $0.15 \pm 0.11^{\mathrm{A}}$ & $0.17 \pm 0.08^{A}$ & $0.29 \pm 0.15^{\mathrm{A}}$ \\
\hline C18:2n-6 & $284 \pm 24^{B}$ & $588 \pm 68^{A}$ & $32 \pm 610^{\mathrm{B}}$ & $464 \pm 38^{A}$ & $0.79 \pm 0.04^{\mathrm{B}}$ & $2.07 \pm 0.09^{A}$ & $1.09 \pm 0.16^{\mathrm{B}}$ & $1.61 \pm 0.12^{\mathrm{A}}$ \\
\hline$C 20: 4 n-6$ & nd & nd & nd & nd & $0.03 \pm 0.01^{\mathrm{A}}$ & $0.04 \pm 0.00^{\mathrm{A}}$ & $0.06 \pm 0.00^{\mathrm{B}}$ & $0.18 \pm 0.05^{\mathrm{A}}$ \\
\hline C18:3n-3 & $1883 \pm 146^{\mathrm{A}}$ & $2170 \pm 131^{A}$ & $2181 \pm 70^{\mathrm{A}}$ & $1712 \pm 104^{\mathrm{B}}$ & $5.17 \pm 0.36^{\mathrm{B}}$ & $7.47 \pm 0.30^{\mathrm{A}}$ & $2.77 \pm 0.18^{\mathrm{B}}$ & $4.86 \pm 0.06^{\mathrm{A}}$ \\
\hline$C 20: 3 n-3$ & $17 \pm 2^{\mathrm{A}}$ & $20 \pm 3^{A}$ & $22 \pm 2^{A}$ & $16 \pm 1^{\mathrm{B}}$ & nd & nd & nd & nd \\
\hline SFA & $1846 \pm 157^{\mathrm{A}}$ & $1778 \pm 189^{A}$ & $2113 \pm 60^{\mathrm{A}}$ & $1542 \pm 102^{\mathrm{B}}$ & $7.71 \pm 0.41^{\mathrm{B}}$ & $10.57 \pm 0.06^{\mathrm{A}}$ & $5.56 \pm 0.07^{\mathrm{B}}$ & $10.05 \pm 0.34^{\mathrm{A}}$ \\
\hline MUFA & $450 \pm 34^{\mathrm{A}}$ & $465 \pm 20^{\mathrm{A}}$ & $519 \pm 21^{\mathrm{A}}$ & $365 \pm 28^{\mathrm{B}}$ & $1.60 \pm 0.07^{\mathrm{B}}$ & $2.04 \pm 0.16^{\mathrm{A}}$ & $0.83 \pm 0.05^{\mathrm{B}}$ & $1.46 \pm 0.23^{\mathrm{A}}$ \\
\hline PUFA & $2183 \pm 171^{\mathrm{B}}$ & $2778 \pm 194^{A}$ & $2529 \pm 81^{A}$ & $2192 \pm 136^{\mathrm{B}}$ & $5.99 \pm 0.40^{\mathrm{B}}$ & $9.58 \pm 0.22^{\mathrm{A}}$ & $3.93 \pm 0.10^{\mathrm{B}}$ & $6.65 \pm 0.10^{\mathrm{A}}$ \\
\hline UFA & $2633 \pm 205^{\mathrm{B}}$ & $3243 \pm 214^{\mathrm{A}}$ & $3048 \pm 102^{\mathrm{A}}$ & $2557 \pm 163^{\mathrm{B}}$ & $7.60 \pm 0.41^{\mathrm{B}}$ & $11.6 \pm 0.06^{\mathrm{A}}$ & $4.75 \pm 0.07^{\mathrm{B}}$ & $8.11 \pm 0.34^{\mathrm{A}}$ \\
\hline TFA & $4480 \pm 361^{A}$ & $5022 \pm 26^{\mathrm{A}}$ & $5161 \pm 162^{\mathrm{A}}$ & $4099 \pm 256^{\mathrm{B}}$ & $15.30 \pm 0.00^{\mathrm{B}}$ & $22.2 \pm 0.00^{\mathrm{A}}$ & $10.32 \pm 0.00^{\mathrm{B}}$ & $18.2 \pm 0.00^{\mathrm{A}}$ \\
\hline N3 & $1900 \pm 147^{\mathrm{A}}$ & $2190 \pm 129^{A}$ & $2203 \pm 71^{\mathrm{A}}$ & $1728 \pm 105^{\mathrm{B}}$ & $5.17 \pm 0.36^{\mathrm{B}}$ & $7.47 \pm 0.30^{\mathrm{A}}$ & $2.77 \pm 0.18^{\mathrm{B}}$ & $4.86 \pm 0.06^{\mathrm{A}}$ \\
\hline N6 & $284 \pm 24^{\mathrm{B}}$ & $588 \pm 68^{A}$ & $326 \pm 10^{\mathrm{B}}$ & $464 \pm 38^{\mathrm{A}}$ & $0.82 \pm 0.04^{\mathrm{B}}$ & $2.11 \pm 0.08^{\mathrm{A}}$ & $1.16 \pm 0.16^{\mathrm{B}}$ & $1.79 \pm 0.17^{\mathrm{A}}$ \\
\hline N6/N3 & $0.15 \pm 0.00^{\mathrm{B}}$ & $0.27 \pm 0.02^{\mathrm{A}}$ & $0.15 \pm 0.00^{\mathrm{B}}$ & $0.27 \pm 0.02^{\mathrm{A}}$ & $0.16 \pm 0.00^{\mathrm{B}}$ & $0.28 \pm 0.02^{\mathrm{A}}$ & $0.42 \pm 0.09^{A}$ & $0.37 \pm 0.04^{\mathrm{A}}$ \\
\hline
\end{tabular}

Value presented in the table is mean \pm s.d.

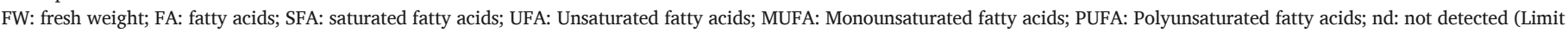
Of Detection $(\mathrm{LOD}) \approx 0.01 \mathrm{mg} / 100 \mathrm{~g} \mathrm{FW}$ ).

For a given lipid fraction and a given fatty acid, means with different capital letter are significantly different for Imbrasia truncata and Imbrasia epimeathea (p < 0.05). 
case contain appreciable levels of indispensable amino acids. Total IAA of I. epimethea and I. truncate (513.3-536.6 mg/g protein; Supplementary data; Table A) were by far higher to the FAO/WHO amino acid reference pattern $(269 \mathrm{mg} / \mathrm{g}$ protein) established for Humans (WHO/ FAO/UNU, 2007) but lower than that of Imbrasia oyemensis (588.4 mg/ $\mathrm{g}$ protein) (Foua Bi, Meite, Dally, Ouattara, \& Kouame, 2015). Each individual indispensable amino acid was also at higher level in I. truncata and I. epimethea than in FAO reference protein (Supplementary data; Table A). Apart phenylalanine + tyrosine and methionine + cysteine, the other indispensable amino acids were lower in protein of I. truncata and I. epimethea than the amount reported for I. oyemensis (Foua Bi et al., 2015). These results showed that proteins of I. truncata and I. epimethea larvae contained good quality amino acids with high biological value. They have a real potential to be used as alternative source of food proteins. A complete evaluation of nutritional value of the protein of these insects would rather include a measurement of their digestibility. In insects, a part of the total protein can be non-digestible for humans and animals due to binding of some proteins to the chitin fibres (Jonas-levi and Martinez, 2017). In the studied Imbrasia caterpillars, even if the chitin fraction represented a limited fraction of the edible part of the insects (less than 5.3-11.1 g/100 g FW, Table 2 ), one cannot exclude such type of interaction decreasing protein digestibility. However, Kwiri et al (2014) reported low difference between crude protein content (55.4\%) and digestible protein (53.3\%) for Gonimbrasia belina caterpillars, which could indicate a low percentage of non-digestible proteins in these kinds of insects.

\subsection{Imbrasia epimethea and Imbrasia truncata larvae contain non protein nitrogen but have fairly standard nitrogen to protein conversion factor}

Nitrogen to protein conversion factors of Imbrasia truncata and Imbrasia epimethea were statistically similar (Table 1 ). That of $I$. truncata $(6.01 \pm 0.21)$ was lower than the value of 6.25 used for most meat products, while that of $I$. epimethea $(6.27 \pm 0.15)$ was close to this value. They were also higher than the value of $4.76 \pm 0.09$ measured for several edible insects (Janssen et al., 2017). However, the percentages of protein nitrogen content, calculated from the composition in amino acid residues, that is for $I$. trunctata $(92.1 \mathrm{~g} / 100 \mathrm{~g} \mathrm{~N})$ and $I$. epimethea $(97.8 \mathrm{~g} /$ $100 \mathrm{~g} \mathrm{~N}$ ) confirmed that in our insects, a small percentage of nitrogen was no protein nitrogen but non protein nitrogen such as chitin, nucleic acids, and phospholipids.

\subsection{Imbrasia caterpillars: a dietary source of $n-3$ fatty acids}

Lipids represent after protein the second main component of $I$. truncata and I. epimethea caterpillars. Total lipid contents of I. truncata and I. epimethea (approximately $23 \mathrm{~g} / 100 \mathrm{~g}$ DW) were higher than results obtained previously on $I$. epimethea: $12.4 \mathrm{~g} / 100 \mathrm{~g}$ DW, Imbrasia truncata 15.2 g/100 g DW (Bukkens, 1997; Mabossy-mobouna et al., 2017) and Gonimbrasia belina: $16.37 \mathrm{~g} / 100 \mathrm{~g}$ DW (Kwiri et al., 2014). The contents were however similar to that reported for I. oyemensis: $23.10 \pm 0.65 \mathrm{~g} /$ $100 \mathrm{~g}$ DW (Foua et al.,2016).

Based on fresh weight, PUFA content of Imbrasia truncata(2.2 $\pm 0.2 \mathrm{~g} / 100 \mathrm{~g}$ FW) and I. epimethea $(2.8 \pm 0.2 \mathrm{~g} / 100 \mathrm{~g}$ FW $)$ were higher than PUFA content of Rhynchophorus phoenicis larvae $(0.76 \pm 0.17 \mathrm{~g} / 100 \mathrm{~g}$ FW $)$ obtained by Fogang et al. (2017). Based on total fatty acid content (Supplementary data, Table B), PUFA contents of total fatty acids of $I$. truncata and I. epimethea were close from resultsobtained by Mabossy-Mobouna (2017) onI. truncata: $51.63 \pm 0.24 \mathrm{~g}$ / $100 \mathrm{~g}$ TFA. They were far higher than the values we measured for $R$. phoenicis larvae: from 2.8 to $5.3 \mathrm{~g} / 100 \mathrm{~g}$ TFA (Fogang Mba et al., 2017, 2018). Epidemiological studies and dietary interventions showed that fatty acid intake plays a key role in human health. PUFAs serve many important functions in the body, including reducing the risk of diabetes by reduction of glu- cose intolerance and prevention of insulin resistance, regulating blood pressure and helping to synthesize and repair vital cell components/ parts (Calder, 2015; FAO, 2010; Imamura et al., 2016; Simopoulos, 2016). I. truncata and I. epimethea are rich in PUFAs, particularly $\alpha$-linolenic acid (C18:3n-3) (Table 7).Their contents were close from the value: $42.63 \pm 0.33 \mathrm{~g} / 100 \mathrm{~g}$ TFA, obtained by Mabossy-Mobouna et al. (2017) on I. truncata. They were higher than those obtained in $I$. belina larvae (19.60 $\pm 0.06 \mathrm{~g} / 100 \mathrm{~g} \mathrm{FA}$ ) (Ekpo et al., 2009)and I. oyemensis larvae (0.82 $\pm 0.02 \mathrm{~g} / 100 \mathrm{~g}$ FA) (Foua et al., 2016). $\alpha$-linolenic acid was also the major fatty acid in several lepidoptera larvae with contents up to $62 \mathrm{~g} / 100 \mathrm{~g}$ FA (Guil-Guerrero et al., 2018).The presence of $\alpha$-linolenic acid in the sn-2 position in TAG is of great importance in nutrition as it can affect their bioavailability (Guil-Guerrero et al., 2018). Therefore, the regi specific distribution of $\alpha$-linolenic acid in TAG of $I$. truncata nd $I$. epimethea larvae lipids need to be investigates. Others PUFAs (C18:2n-6 and C20:3n-3) are also present at low levels. Alpha-linolenic acid (ALA) and linoleic acid (LA) are respectively precursors of $n-3$ and $n-6$ long chain PUFAs families in humans. They are essential fatty acids that must be supplied by the diet of humans and other mammals because of the lack of endogenous enzymes for omega-3 desaturation(Stanley-Samuelson et al., 1988). The concentration of C18:3n-3 in I. truncata $(42.04 \pm 0.20 \mathrm{~g} / 100 \mathrm{~g}$ TFA) and $I$. epimethea larvae $(43.21 \pm 2.40 \mathrm{~g} / 100 \mathrm{~g}$ TFA)agree with the value of $42.63 \pm 0.33 \mathrm{~g} / 100 \mathrm{~g}$ TFA found for $I$. truncata larvae(Mabossy-Mobouna et al., 2017). They are higher than the values of $36.8 \mathrm{~g} / 100 \mathrm{~g}$ TFA for $I$. truncate and $35.1 \mathrm{~g} / 100 \mathrm{~g}$ TFA for I. epimethea larvae(Bukkens, 1997). Long-chain PUFA such as arachidonic (AA), eicosapentaenoic (EPA) and docosahexaenoic (DHA) acids were however not detected in the larvae lipids contrary to Apkossan which reported having identified arachidonic acid in the lipids extracted from Imbrasia Oyemensis on the basis of GC retention times (Akpossan et al., 2015). The abundance of $n-3$ PUFAs in the form of $\alpha$-linolenic acid in Imbrasia larvae lipids are linked to their diet, which are mainly composed of leaves. The FA content of insect are linked to their diets (Guil-Guerrero et al., 2018). Omega-3 fatty acids have strong anti-inflammatory effects, reduce blood pressure and insulin resistance (Rustan and Drevon, 2001). The concentration of C18:2n-6 in I. truncata $(6.33 \pm 0.06 \mathrm{~g} / 100 \mathrm{~g}$ FA $)$ and I. epimethea larvae $(11.70 \pm 1.29 \mathrm{~g} / 100 \mathrm{~g}$ FA) are close to the value of $6.58 \pm 0.03 \mathrm{~g} / 100 \mathrm{~g}$ FA measured in $I$. oyemensis larvae (Gonimbrasia (Nudaurelia) menalops)(Foua et al., 2016) and $6.02 \mathrm{~g} / 100 \mathrm{~g}$ FA in I. belina larvae (Gonimbrasia belina) (Ekpo et al., 2009). Omega-6 fatty acids also have many beneficial effects with respect to cardiovascular diseases (hyperlipidaemia, atherogenesis, leucocyte reactivity, immunological functions and cardiac arrhythmias)(Rustan and Drevon, 2001). Lack of essential fatty acids also promotes skin inflammation and delays wound healing (Rustan and Drevon, 2001).

The daily requirement intake for adults is $4.4 \mathrm{~g}$ /day for linoleic acid and $1.8 \mathrm{~g}$ /day for $\alpha$-linolenic acid (Anses, 2011). A serving size (20 insects) of fresh I. truncata (144 g) and I. epimethea larvae (121 g)will provide respectively $2.72 \mathrm{~g}$ and $2.62 \mathrm{~g} \alpha$-linolenic acid. Thus they represent respectively $151 \%$ and $146 \%$ of daily requirement intake of this essential fatty acid. A serving size (20 insects) of fresh I. epimethea $(144 \mathrm{~g})$ and I. truncata $(121 \mathrm{~g})$ will provide respectively 0.41 and $0.71 \mathrm{~g}$ of linoleic acid. These will represent respectively $9.29 \%$ and $16.2 \%$ of daily requirement intake.

Nutritionally, the $n-6 / n-3$ ratio is also important. The $n-6 / n-3$ ratios in total lipids of $I$. truncata and $I$. epimethea larvae were lower than 0.3.Guil-Guerrero et al (2018) obtained ratios lower than the value of one for 12 lepidoptera larvae. They are lower than the maximum target value of 5(ANSES, 2015) and thus may participate to the re-equilibration of the current lipid dietary intake, characterized in most countries by too high n-6/n-3 levels. Many studies suggested that an unbalanced consumption of $n-6 / n-3$ ratio is associated with human chronic diseases. An equilibrated $n-6 / n-3$ ratio has positive effects on 
the prevention of coronary heart disease (CHD), hypertension, reducing total mortality; it also would decreases the risk of breast cancer and many other diseases (diabetes, arthritis, autoimmune and neurodegenerative diseases (Simopoulos, 2016, 2010) even if the possible mechanisms and effectiveness remain highly debated (Albracht-schulte et al., 2018; Wei et al., 2018).

\subsection{Imbrasia caterpillars as complementary source of energy}

Energy content of I. truncata and $I$. epimethea were respectively $633.0 \mathrm{~kJ}(151.3 \mathrm{kcal}) / 100 \mathrm{~g} \mathrm{FW}$ and $613.3 \mathrm{~kJ}(146.6 \mathrm{kcal}) / 100 \mathrm{~g}$ FW. As the dietary energy intake of a healthy young men (between 18 and 30 years old, 65 and $70 \mathrm{~kg}$ ) in active or moderately active lifestyle is 3 $100 \mathrm{kcal} /$ day (FAO, 2001), a serving size (20 insects) of fresh I. truncata $(144 \mathrm{~g})$ and $\mathrm{I}$. epimethea larvae $(121 \mathrm{~g})$ will provides respectively 217 and $180 \mathrm{kcal}$ of energy. Energy content of I. truncata and I. epimethea larvae were lower than that of palm weevil (Rhynchophorus phoenicis) larvae $(940.0 \mathrm{~kJ}$ (224.7 kcal)/100 gFW) (Fogang Mba et al., 2017). These two types of insects, with different nutritional characteristics, are consumed by same population. Contrary to palm weevillarvae which can be considered as an energetic food due to their high lipid contents, the caterpillars of $I$. truncata and $I$. epimethea can be used to re-equilibrate high lipid content diets.

\subsection{Imbrasia truncata and Imbrasia epimethea are source of Vitamin $E$}

Tocopherol contents of lipids of Imbrasia truncata(119.7 $\pm 16.5 \mu \mathrm{g} /$ $\mathrm{g}$ lipids)and Imbrasia epimethea(224.4 $\pm 22.5 \mu \mathrm{g} / \mathrm{g}$ lipids)were higher than the contents of mophane (I. belina) oil: $73 \mu \mathrm{g} / \mathrm{g}$ lipid (Yeboah and Mitei, 2009). Our results showed different repartition of tocopherol isomers in the two Imbrasia species. The major tocopherol isomer was $\alpha$-tocopherol in $I$. truncata (77 $\pm 11 \mu \mathrm{g} / \mathrm{g}$ lipids), while it was $\gamma$-tocopherol in I. epimethea $(150 \pm 12 \mu \mathrm{g} / \mathrm{g}$ lipids) (Table 4$)$. $\alpha$-tocopherol content of total lipids of $I$. truncata and I. epimethea was different to $\alpha$-tocopherol content of mophane oil: $72 \mu \mathrm{g} / \mathrm{g}$ lipids(Yeboah and Mitei, 2009). $\alpha$-tocopherol supplied by $100 \mathrm{~g}$ I. truncata or I. epimethea larvae $(0.41$ to $0.52 \mathrm{mg} / 100 \mathrm{~g} \mathrm{FW}$ ) is also lower than the value reported for Tenebrio molitor larvae (1.9 mg/100 g FW) (Nowak et al, 2016).Total tocopherol content of $I$. truncata $(1.5 \pm 0.2 \mathrm{mg} / 100 \mathrm{~g} \mathrm{FW})$ and $I$. epimethea $(0.8 \pm 0.1 \mathrm{mg} / 100 \mathrm{~g} \mathrm{FW})$ larvae were in the same order range than that of cricket $(2.3 \pm 1.8 \mathrm{mg} / 100 \mathrm{~g} \mathrm{FW})$, honey bee $(0.6 \pm 0.4 \mathrm{mg} / 100 \mathrm{~g}$ FW) and black soldier fly (0.62 mg/100 g FW) (Payne et al., 2015). They were lower to the values found for palm weevil (Rhynchophorus Phoenicis) larvae: 2.3 to $4.8 \mathrm{mg} / 100 \mathrm{~g} \mathrm{FW}$, depending on larvae morphotype (Fogang Mba et al., 2017, 2018). As the recommend nutrient intake of $\alpha$-tocopherol is $10 \mathrm{mg} /$ day (FAO, 2001), the consumption of $100 \mathrm{~g}$ of these insects will contribute up to $15 \%$ of Vitamin E recommend nutrient intake. These insects can be considered as source of vitamin $\mathrm{E}$. The presence of tocopherols in these insects may also be useful in protection of the lipids of these insects from oxidation during processing of raw insects into derived products (drying, cooking, etc). These tocopherol contents of Imbrasia truncata and Imbrasia epimethea should be carefullyconsidered. Indeed, it could vary with the season, as it is known that the tocopherol content of plants, on which insect feed, varies with the season and vegetation. This is the case, for example, with flax (Teneva et al., 2014).

\subsection{Lipolytic enzymes are very active in Imbrasia truncata and Imbrasia epimethea}

Total lipids of $I$. truncata and I. epimethea were majorly composed of neutral lipids.The neutral lipid fractions extracted from the larvae killed by freezing and further stored at frozen state were majorly composed of free fatty acids. In animal as in vegetal worlds, the molecular form for storage lipids is triacylglycerols. These storage molecules are hydrolysed in vivoto liberate free fatty acids available for body physiological needs. Hydrolysis also takes place when tissues and cellular injuries provoke contact between the lipolytic enzymes and their substrates. We assume that the presence of free fatty acids was due to the hydrolysis of the triacylglycerols taking place between the harvest of the larvae and lipid extraction and that the viscera and other organs of Imbrasia larvae contained very active lipases which are able to efficiently hydrolyse lipids. Boiling of insects immediately after their killing by freezing had accordingly permitted to reduce the level of free fatty acids in the neutral lipids of $I$. truncata larvae. Free fatty acids are generally considered as lowering food quality because their favour enzymatic and non-enzymatic oxidation of PUFAs. Thus, the possibility to inactivate efficiently the lipolytic activities in the Imbrasia larvae, just after their harvest, should be investigated.

\subsection{Polar lipids of Imbrasia truncata and Imbrasia epimethea larvae present untypical composition}

Polar lipids (phospholipids and the fraction soluble in acetone) were found in low proportions in total lipids of Imbrasia truncata and Imbrasia epimethea, less than $6 \mathrm{~g} / 100 \mathrm{~g}$ total lipids (Table 5). Ekpo et al. (2009) found higher proportions of polar lipids in I. belina total lipids: $4.16 \pm 0.21 \mathrm{~g} / 100 \mathrm{~g}$ for glycolipids and $9.87 \pm 0.35 \mathrm{~g} / 100 \mathrm{~g}$ for phospholipids.

Phospholipids of $I$. truncata and $I$. epimethea larvae contained $62-71 \mathrm{~g} / 100 \mathrm{~g}$ sphingomyelin (Table 6). This is highly higher than in muscles of most animal and current foods(Weihrauch and Son, 1983). As compared to neutral lipids, phospholipids contained lower levels of unsaturated fatty acids. This lower level of unsaturated fatty acids can be explained by the abundance of sphingomyelin in polar lipids. More study must be done to clearly define if the high level of sphingomyelin in phospholipid composition is related to the insect species or to their stage of development.

The knowledge of lipid classes and their fatty acid compositions are important as they can affect nutritional impact of dietary lipids (Meynier and Genot, 2017). It can also be important for a further valorisation and transformation of the insects for marketing and industrial applications. Indeed, dietary lipids are not only sources of energy and nutrients, but are actively involved in properties such as texture, sensory properties and participate to the overall acceptability of foods (Meynier and Genot, 2017).

\section{Conclusion}

The results presented in this article indicate that $I$. truncata and $I$. epimethea larvae have a great potential to be used as source of dietary proteins and dietary lipids. These insects also contain indispensable amino acids at levels higher than the protein reference of FAO. They could thus serve as an alternative dietary supplement of proteins, able to narrow the amino acid deficits that are prevalent in many developing countries. These insects also contain important amounts of $\alpha$-linolenic acid, the consumption of $100 \mathrm{~g}$ of fresh insect covering the daily reference intake. Their $n-6 / n-3$ ratios were lower than 0.3 which is appreciable in prevention of several diseases. These insects also contain tocopherols. Indeed, if they have an appreciable nutrient composition, many others factors can contribute to limit their consumption, among them the efficient lipolysis of their neutral lipids. Researches are needed to optimize their lipid extraction without lipolysis. Besides, detailed analysis of these Imbrasia species for other nutrients, anti-nutrients and secondary metabolites with medicinal potential should be considered. The results from the present analysis might strengthen the use of this insect as a supplement of protein, amino acids and $\alpha$-linolenic acid in foods. 


\section{Conflict of interest}

The authors declare no conflict of interest

\section{Funding}

This work was supported in part by the SCAC (Service de Coopération et d'Action Culturelle) of the French Embassy of Yaoundé Cameroon [Code projet Prisme/Numéro Prisme: 0185 CMR B16 0011]. https://cm.ambafrance.org/Bourses-du-gouvernement-francais

The DNA barcoding process was funded through the international Barcode of Life project (iBOL) supported by Genome Canada through the Ontario Genomics Institute, Canada Foundation for Innovation, and by the Ontario Ministry for Research and Innovation.

\section{Acknowledgements}

The authors wish to thank Christian Blassel, Véronique Solé-Jamault, Lucie Ribourg and Nordine Hafnaoui for helping us respectively in insect lyophilization and water analysis, protein analysis, tocopherol analysis, and amino acid analysis.

\section{Appendix A. Supplementary data}

Supplementary material related to this article can be found, in the online version, at doi:https://doi.org/10.1016/j.jfca.2019.03.002.

\section{References}

Akpossan, R., Digbeu, Y.D., Parfait, J., Eugène, N., Dabonné, S., Dué, E.A., Kouamé, L.P., 2014. IJRB Nutritional characteristics of the caterpillars (Imbrasia oyemensis) from Côte d'Ivoire. Int. J. Recent Biotechnol. 2, 1-5.

Akpossan, R.A., Due, E.A., Koffi, D.M., Kouame, P., 2015. Fatty acids, mineral composition and physico-chemical parameters of Imbrasia oyemensis larvae oil with unusual arachidonic acid content. J. Faculty of Food Eng. 14, 358-367.

Albracht-Schulte, K., Sudheera Kalupahana, N., Ramalingam, L., Wang, S., Rahman, S.M., Robert-McComb, J., Moustaid-Moussa, N., 2018. Omega-3 fatty acids in obesity and metabolic syndrome: a mechanistic update. J. Nutr. Biochem. 58, 1-16.

Anses, 2011. Actualisation Des Apports Nutritionnels Conseillés Pour Les Acides Gras. Rapport D'expertise Collective 2011. n 2006-SA-03359 ANC AG 323.

ANSES, 2015. En Acides Gras De La Population Vivant En France Et Comparaison Aux Apports Nutritionnels Conseillés Définis En 2010. Avis De l'ANSES, Rapport d'étude, Saisine $N^{\circ}$. « 2014-SA-0117 » 244 pp.

Anvo, M.P.M., Toguyéni, A., Otchoumou, A.K., Zoungrana-kaboré, C.Y., Kouamela, E.P., 2016. Nutritional qualities of edible caterpillars Cirina butyrospermi in southwestern of Burkina Faso. Int. J. Innov. Appl. Stud. 18, 639-645.

AOAC, 1996. Official Methods of Analysis of AOAC International, 16th ed. Association ofOfficial Analytical Chemists, Gaithersburg, MD, USA.

Balinga, M.P., Monzambe Mapunzu, P., Moussa, J.B., N'gasse, G., 2004. Contribution des insectes de la forêt à la sécurité alimentaire. L'exemple des chenilles d'Afrique Centrale. Programme des Produits Forestières Non- Ligneux. FAO, 107 pp.

Bukkens, S.G.F., 1997. The nutritional value of edible insects. Ecol. Food Nutr. 36, 287-319.

Calder, P.C., 2015. Functional roles of fatty acids and their effects on human health. J. Parenter. Enter. Nutr. 8, 18-32.

Dube, S., Dlamini, N.R., Mafunga, A., Mukai, M., Dhlamini, Z., 2013. A survey on entomophagy prelence in Zimbabwe. Afr. J. Food Agric. Nutr. Dev. 13 (1), 7242-7253.

Dumas, J.B.A., 1831. Procédés de l'analyse Organique. Annales de Chimie et de Physique $2,198-213$.

EFSA, 2012. Scientific opinion on dietary reference values for protein. EFSA Panel on Dietetic Products, Nutrition and Allergies (NDA). Efsa J. 10, 108.

Ekpo, K.E., Onigbinde, A.O., Asia, I.O., 2009. Pharmaceutical potentials of the oils of some popular insects consumed in southern Nigeria. Afr. J. Pharm. Pharmacol. 3, 051-057.

FAO, 2001. Human Energy Requirements: Report of a Joint FAO/WHO/UNU Expert Consultation. 0 FAO Food and Nutrition Technical Report Series, 96 http://doi.org/ 9251052123 .

FAO, 2010. Fats and fatty acids in human nutrition: report of an expert consultation. Rome.

FAO - FIDA - WFP, 2015. L'état de l'insécurité alimentaire dans le monde 2015. Objectifs internationaux 2015 de réduction de la faim: des progrès inégaux. Organisation des Nations Unies pour l'alimentation et l'agriculture (FAO), Fonds international de développement agricole (FIDA), Programme Alimentaire Mondial (WFP)https://doi. org/10.1024/1012-5302.16.6.384.
Fogang Mba, A.R., Kansci, G., Viau, M., Hafnaoui, N., Meynier, A., Demmano, G., Genot, C., 2017. Lipid and amino acid profiles support the potential of Rhynchophorus phoenicis larvae for human nutrition. J. Food Compos. Anal. 60, 64-73.

Fogang Mba, A.R., Kansci, G., Viau, M., Ribourg, L., John Fogoh, M., Hafnaoui, N., Le Gall, P., Genot, C., 2018. Growing conditions and morphotypes of African palm weevil (Rhynchophorus phoenicis) larvae influence their lipophilic nutrient but not their amino acid compositions. J. Food Compos. Anal. 69, 87-97.

Folch, J., Lees, M., Stanley, G.H.S., Sloane Stanley, G., 1957. A simple method for the isolation and purification of total lipides from animal tissues. J. Biol. Chem. 226, 497-509.

Foua, B.F.G., Meite, A., Dally, T., Ouattara, H., Kati Coulibaly, S., 2016. Biochemical and nutritional study of powder from caterpillars Imbrasia oyemensis eaten in west of Côte d'Ivoire. Sky J. Biochem. Res. 5, 24-30.

Foua Bi, F.G., Meite, A., Dally, T., Ouattara, H., Kouame, K.G., 2015. Étude de la qualité biochimique et nutritionnelle de la poudre séchée d'Embrasa oyemensis. chenilles consommées au Centre-Ouest de la Côte d'Ivoire 96, 9039-9048.

Glew, R.H., Jackson, D., Sena, L., Vanderjagt, D.J., Pastuszyn, A., Millson, M., 1999. Gonimbrasia belina (Lepidoptera: Saturniidae): a nutritional food source rich in protein, fatty acids, and minerals. Am. Entomol. 45, 250-253.

Guil-Guerrero, J.L., Ramos-Bueno, R.P., Gonzàlez-Fernàndez, M.J., Fabrikov, D., Sànchez-Muros, M.J., Barroso, F.G., 2018. Insects as food: fatty acid profiles, lipid classes,andsn-2 fatty acid distribution of lepidoptera larvae. Eur. J. Lipid Sci. Technol. $120,1-11$.

Hebert, P.D.N., Cywinska, A., Ball, S.L., Jeremy, R., 2003. Biological identifications through DNA barcodes. R. Soc. 270, 313-321.

Imamura, F., Micha, R., Wu, J.H.Y., Otto, M.C.D.O., Otite, F.O., Abioye, A.I., Mozaffarian, D., 2016. Effects of saturated fat, polyunsaturated fat, monounsaturated fat, and carbohydrate on glucose-insulin homeostasis : a systematic review and meta-analysis of randomised controlled feeding trials. PLoS Med. 13, 1-18.

Janssen, R.H., Vincken, J.P., van den Broek, L.A.M., Fogliano, V., Lakemend, C., 2017. Nitrogen-to-protein conversion factors for three edible insects :Tenebrio molitor, Alphitobius, and Hermetia illucens. J. Agric. Food Chem. 65, 2275-2278.

Jonas-levi, A., Martinez, J.I., 2017. The high level of protein content reported in insects for food and feed is overestimated. J. Food Compos. Anal. 62, 184-188.

Kates, M., 1972. Techniques for separation of lipid mixtures. In: Work, T.S., Work, E. (Eds.), Techniques of Lipidology: Isolation, Analysis and Identification of Lipids (Series 'Laboratory Techniques in Biochemistry and Molecular Biology. North-Holland Publishing Company, Amsterdam, pp. 398-404.

Kokondi, K., Leclercq, M., Bourgeay-Causse, M., Pascaud, A., Gaudin-Harding, F., 1987. Intérêt nutritionnel de chenilles d'attacidés du Zaîre: composition et valeur nutritionnelle. Cahier de Nutrition et de Diététique 22, 473-477.

Kwiri, B.R., Winini, C., Muredzi, P., Tongonya, J., Gwala, W., Mujuru, F., Gwala, S.T., 2014. Mopane worm (Gonimbrasia belina) utilisation, a potential source of protein in fortified blended foods in Zimbabwe: a review. Global J. Sci. Front. Res.: D Agric. Vet. 14, 55-67.

Latham, P., 2008. Les chenilles comestibles et leurs plantes nourricières dans la province du Bas-Congo. ISBN : 978-0-9554208-6-3.

Lautenschläger, T., Neinhuis, C., Kikongo, E., Henle, T., Förster, A., 2017. Impact of different preparations on the nutritional value of the edible caterpillar Imbrasia epimethea from northern Angola. Eur. Food Res. Technol. 243, 769-778.

Lisingo, J., Wetsi, J., Ntahobavuka, H., 2010. Enquête sur les chenilles comestibles et les divers usages de leurs plantes hôtes dans les districts de Kisangani et de la Tshopo ( $\mathrm{R}$. D. Congo ). GeoEcoTrop 34, 139-146.

Mabossy-Mobouna, G., Kinkela, T., Lenga, A., Malaisse, F., 2013. Imbrasia truncata Aurivillius (Saturniidae): importance en Afrique Centrale, commercialisation et valorisation à Brazzaville. GeoEcoTrop 37, 313-330.

Mabossy-Mobouna, G., Lenga, A., Latham, P., Kinkela, T., Konda, A., Mbuta, K.U., Bouyer, T., Roulon-doko, P., Malaisse, F., 2016. Clef de détermination des chenilles de dernier stade consommées au Congo-Brazzaville. GeoEcoTrop 40, 75-103.

Mabossy-Mobouna, G., Kinkela, T., Lenga, A., 2017. Apports nutritifs des chenilles d' Imbrasia truncata consommées au Congo-Brazzaville. J. Anim. Plant Sci. 31, 5050-5062.

Meynier, A., Genot, C., 2017. Molecular and structural organization of lipids in foods: their fate during digestion and impact in nutrition. OCL, Oilseeds Fats Crops and Lipids 24, $1-12$.

Micha, R., Khatibzadeh, S., Shi, P., Andrews, K.G., Engell, R.E., Mozaffarian, D., 2015. Global, regional and national consumption of major food groups in 1990 and 2010 : a systematic analysis including 266 country-speci fi c nutrition surveys worldwide. British Med. J. Open 5, 1-23.

Morrison, W.R., Smith, L.M., 1964. Preparation of fatty acid methyl esters and dimethyl acetals from lipids with boron trifluoride methanol. J. Lipid Res. 5, 600-608.

Nowak, V., Persijn, D., Rittenschober, D., Charrondiere, U.R., 2016. Review of food composition data for edible insects. Food Chem. 193, 39-46.

Oberprieler, R., 1997. Classification of the African Saturniidae (Lepidoptera) the quest for natural groups and relationships. Metamorphosis (Supplement3) 142-155.

Okangola, E., Solomo, E., Tchatchambe, W.B., Mate, M., Upoki, A., Dudu, A., Asimonyio, J.A., Bongo, G.N., Mpiana, P.T., Ngbolua, K.-N., 2016. Valeurs nutritionnelles des chenilles comestibles de la ville de Kisangani et ses environs (Province de la Tshopo, République Démocratique du Congo). Int. J. Innov. Sci. Res. 25, 278-286.

Oliveira, Santos, Passos de Carvalho, J.F., Bruno de Sousa, J., R. F. X., Simao, M.M., 1976. The nutritional value of four species of insects consumed in Angola. Ecol. Food Nutr. 5, 91-97. 
Payne, C.L., Scarborough, P., Rayner, M., Nonaka, K., 2015. A systematic review of nutrient composition data available for twelve commercially available edible insects, and comparison with reference values. Trends Food Sci. Technol. 47, 69-77.

Raksakantong, P., Meeso, N., Kubola, J., Siriamornpun, S., 2010. Fatty acids and proximate composition of eight Thai edible terricolous insects. Food Res. Int. 43, 350-355.

Ramos-Elorduy, J., Moreno, Pino, Prado, J.M., Perez, E.E., Otero, M.A., J. L., de Guevara, O.L., 1997. Nutritional value of edible insects from the state of Oaxaca, Mexico. J. Food Compos. Anal. 10, 142-157.

Ratnasingham, S., Hebert, P.D.N., 2013. A DNA-based registry for all animal apecies : the barcode index number (BIN) system. PLoS One 8, 1-16.

Rougerie, R., Estradel, Y., 2008. Morphology of the preimaginal stages of the African emperor moth Bunaeopsislicharbas (Maassen and Weyding): phylogenetically informative characterswithin the Saturniinae (Lepidoptera: saturniidae). J. Morphol. 2, 207-232.

Rumpold, B.A., Schlüter, O.K., 2013. Nutritional composition and safety aspects of edible insects. Mol. Nutr. Food Res. 57, 802-823.

Rustan, A.C., Drevon, C.A., 2001. Fatty acids: structures and properties. Encycl. Life Sci. $1-7$.

Sihamala, O., Bhulaidok, S., Li-rong, S., Duo, L., 2010. Lipids and fatty Acid composition of dried edible red and black ants. Agric. Sci. China 9, 1072-1077.

Simopoulos, A.P., 2010. The omega-6/omega-3 fatty acid ratio: health implications. OCL Oleagineux Corps Gras Lipides 17, 267-275.

Simopoulos, A.P., 2016. An increase in the Omega-6/Omega-3 fatty acid ratio increases the risk for obesity. Nutrients $8,1-17$.

Stanley-Samuelson, D.W., Jurenka, Ra., Cripps, C., Blomquist, G.J., de Renobales, M., 1988. Fatty acids in insects: composition, metabolism, and biological significance. Arch. Insect Biochem. Physiol. 9, 1-33.

Tabuna, H., 2000. Evaluation des échanges des produits forestiers non ligneux entre l'Afrique Subsaharienne et l'Europe. FAO et Agence des Etats Unis pour le développement International (USAID), Programme régional centrafricain pour l'environnement (CARPE), Rome.

Teneva, O., Zlatanov, M., Antova, G., Marcheva, M., 2014. Changes of composition in triacylglycerols, sterols and tocopherols of flax during the vegetation. Bulgarian J. Agric. Sci. 20, 112-116.

Vaglia, T., Haxaire, J., Kitching, I.J., Meunier, I., Rougerie, R., 2008. Morphology and DNA barcoding reveal three cryptic species within the Xylophanes neoptolemus and loelia species-groups (Lepidoptera: sphingidae). Zootaxa 1923, 18-36.

Van Huis, A., Van Itterbeeck, J., Klunder, H., Mertens, E., Halloran, A., Muir, G., Vantomme, P., 2013. Edible Insects. Future Prospects for Food and Feed Security Vol.171, Food and Agriculture Organization of the United Nations.

Wei, J., Hou, R., Xi, Y., Kowalski, A., Wang, T., Yu, Z., Ali, M.K., 2018. The association and dose - response relationship between dietary intake of $\alpha$-linolenic acid and risk of CHD : a systematic review and meta-analysis of cohort studies. Brit. J. Nutr. 119, 83-89.

Weihrauch, J.L., Son, Y.S., 1983. Phospholipid content of foods. J. Am. Oil Chem. Soc. 60 , 1971-1978.

WHO/FAO/UNU, 2007. Protein and Amino Acid Requirements in Human Nutrition. Retrieved from World Health Organization technical report serieshttp://www.ncbi.nlm. nih.gov/pubmed/18330140.

Yang, L.F., Siriamornpun, S., Li, D., 2006. Polyunsaturated fatty acid content of edible insects in Thailand. J. Food Lipids 13, 277-285.

Yeboah, S.O., Mitei, Y.C., 2009. Further lipid profiling of the oil from the mophane caterpillar, Imbrasia belina. J. Am. Oil Chem. Soc. 86, 1047-1055.

Zielińska, E., Baraniak, B., Karaś, M., Rybczyńska, K., Jakubczyk, A., 2015. Selected species of edible insects as a source of nutrient composition. Food Res. Int. 77, $460-466$. 